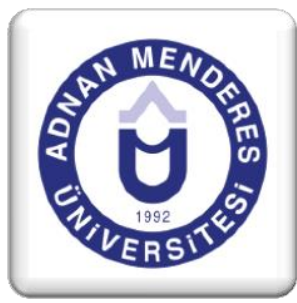

\title{
Avrupalı Gezginler Gözüyle 19. Yüzyılda Aydın ve Çevresi *
}

\section{Aydin and It's Surroundings in the $19^{\text {th }}$ Century from the Eyes of European Travelers}

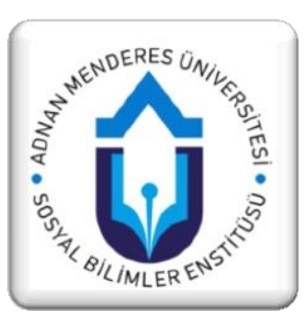

\section{Özet}

Osmanlı Devleti'nin dağılma dönemini içine alan 19. yüzyıl, bu dağılmaya engel olunmaya çalışırken yabancı devletlere ve Osmanlı bünyesindeki azınlıklara verilen sayısı tavize de tanıklık etmiştir. Bu dönemde bu topraklara olan ilgi Avrupa'da öncelikle devletler, sonrasında kurum ve kuruluşlar, son olarak da bireyler düzeyinde farklı nedenlerle artmış; bölgeye farklı amaçlarla gelen pek çok Avrupalı gezgin ilgi alanlarına giren araştırma ve incelemelerin yanı sıra bu coğrafyadaki yaşamı, kültürel ve sosyal çevreyi de kaleme almıştır. Batı Anadolu da Avrupa'da uyanan bu meraktan payına düşeni almış, bu coğrafi alanda gözlem ve izlenimlerini kaleme alan pek çok gezgin zamanın Batı Anadolu'suna dair deneyim ve yaşantılarını da paylaşmıştır.

19. yüzyılda Aydın ve çevresindeki yaşantının Avrupalı on dört gezgin gözüyle kaleme alındığı bu çalışmada, öncelikli kaynaklar olarak gezginlerin izlenimlerini kendi cümleleriyle anlattıkları seyahatnamelere başvurulmuştur. Gezi yazısı da denilen seyahatnamelerin önemi tartışılmış ve söz konusu Avrupalı gezginlerin bu coğrafya hakkındaki gözlem ve izlenimleri paylaşılmıştır. Avrupalı gezginlerin gözlem ve izlenimleri "Türk halkı, yaşantısı, şehirleri, kadınlar, giyim, konaklama, azınlıklar, nüfusa dair izlenimler ve yönetim" konu başlıkları altında incelenmektedir.

Anahtar Kelimeler: Aydın, gezgin, seyahatname, 19. Yüzyıl

\section{Abstract}

$19^{\text {th }}$ century, including the dissolution period of the Ottoman Empire, witnessed many concessions made for the foreign states and the minority under the Ottoman Rule during the struggle to prevent the mentioned dissolution. Various motives raised the European curiosity and interest on the Ottoman Land of first the states, then institutions and organizations, and finally that of individuals; and the numerous European travelers who visited the region with various motives also wrote about the life, cultural and social environment besides their examination and research activities. 
Western Anatolia also took its share from the mentioned curiosity, and many travelers having written their observations and impressions also shared their experience and lives in the Western Anatolia of the time.

In this study, where life in Aydın and its surroundings in the $19^{\text {th }}$ century has been consigned to writing from the eyes of fourteen European travelers; the travel books in which the travelers reflected their impressions with their own phrases, were referred to as prior resource materials. The importance of travel books was discussed, and the observations and impressions of the mentioned travelers were presented. The observations and impressions of these European travelers were given under such different headlines as "Turkish people, life, towns, women, dressing, accommodation, population and minorities and administration".

Key Words: Aydın, traveler, travel book, $19^{\text {th }}$ century

\section{GİRIŞ̧}

Arapça "seyahat" ve Farsça "nâme" sözcüklerinin birleşiminden oluşan seyahatname; yazarların yurt içinde ve yurt dışında yaptığı gezilerde gördükleri yerlerin ilgi çeken, değişik olan taraflarını yalın ve samimi bir anlatımla yansıttığı yazılardır (T.D.K. Türkçe Sözlük C.3, 1988:1291). Seyyah ise gezmek, tanımak, görmek, dinlenmek amacıyla geziye çıkan kimseye denir (T.D.K. Türkçe Sözlük C.1, 1988:546). Her dönem ve şehrin sosyal, kültürel, ekonomik ve siyasal tarihini inceleyenler için otantik değeri olan kaynaklardan biri olan seyahatnameler; yazıldıkları coğrafya, kültür ve sosyal çevreye dair verdikleri bilgiler nedeniyle tarih araştırmaları için vazgeçilmez nitelikte birinci elden kaynaklardır.

Bununla birlikte seyahatnamelerin tarih araştırmalarında nasıl kullanılması gerektiği, nesnel olup olmadıkları pek çok tarihçi, yazar ve araştırmacı arasında tartışma konusu olmuştur. Tartışmaların temelinde seyahatnamelerin çoğunlukla öznel bilgiler içerdiği ve seyyahların bölge ile ilgili izlenimlerini tarafsız bir şekilde yansıtmadığı görüşü ağır basmaktadır. Söz konusu öznellik aslında çok da kaçınılması ve uzak durulması gereken bir husus değildir. Her devletin kendi okullarında okutulan tarih kitaplarının tamamen objektif bilgi içereceğinin garantisi bulunmadığ milletlerden bireylerin kendilerine tamamen yabanc1 olan bir coğrafyayı da kendi ülkelerinin bireylerine aşıladığı değer yargıları ve hatta önyargılardan uzak olarak değerlendirmesini beklemek çok da gerçekçi bir yaklaşım değildir. Gezgin; yabancı topraklara ilişkin bilgiyi önce kendi ülkesinde öğrenir, kendi tarih kitaplarından bilgi edinir, sonra söz konusu topraklarda bulunmuş başka gezginlerin eserlerini inceler ve aslında yolculuğa çıkacağı coğrafya hakkındaki bilgiyi, fakat daha önemlisi duyguyu yola çıkmadan önce edinir.

Avrupalı gezginlerin pek çoğunun, seyahatnamelerini kaleme almaya başlamadan önce, gidecekleri topraklarda kendilerinden evvel bulunmuş diğer gezginlerin seyahatnamelerini okuduğu hemen her gezginin yazısında açıkça dile getirilmektedir. Gezgin öncelikle kendisinden önceki bireyin fikirlerini alır ve farkında olmadan belirli bir önyargıyla yola çıkar. Ne göreceğini başkasının gözünden görmüştür, ne hissedeceğini başkasının anlatımıyla hissetmiştir. $\mathrm{Bu}$ açıdan bakıldığında seyahatnamelerin objektif yazın türleri olmasını beklemek en baştan yanlış olacaktır. Fakat unutulmamalıdır ki, bu öznellik bile önemli bir bilgiye kaynaklık eder. Bu sayede seyahatnameler; söz 
konusu toplumun bahse konu coğrafya, kültür ve sosyal çevre hususlarındaki öğretileri hakkında bilgi sağlamış olurlar. $\mathrm{Bu}$ öznelliğin üzerinde bu derece durmak abartılı değildir; zira söz konusu seyahatname ise öznellik, ilk önce akla gelmesi, fakat daima olumsuz yönleriyle düşünülmemesi gereken bir özelliktir. Avrupalı gezginlerin Batı Anadolu üzerine kaleme aldıkları seyahatnamelere değinirken, bir gezginin bu coğrafya insanı hakkında daima olumsuz şekilde söz edeceğini düşünmemek gerekir; çünkü Türk insanı ve Osmanlı Devleti'ne dair olumlu izlenimlerini aktaran pek çok gezgin de bulunmaktadır.

Batı ve Doğu kavramlarına değinmek gerekirse, Batı'da Doğu'ya yönelik uyanan merakın temelleri de oldukça yerindedir. Avrupa'yı Osmanlı Devleti'nden ayıran en önemli fark, dindir. Çalışma konusunda gezginleri "Avrupalı" olarak gruplandırmamızın temel sebebi de Avrupa devletlerinin ve milletlerinin aynı dine ve dolayısıyla benzer toplumsal doktrinlere tabi olmasıdır. Burada din sadece "inançlar ve ibâdetler bütünü” olarak algılanmamalıdır. Her dinin inananlarına öğütlediği davranışlar, yaşantı biçimleri, eylemler, ahlaki değerler bulunmaktadır. Söz konusu inananlardan oluşan toplumlar da bu dinin esaslarına göre şekillenmektedir. Charles Fellows ${ }^{1}$, seyahatnamesinin bir bölümünde Türk insanının misafirperverliğinden şu şekilde bahseder: "Sabahleyin kahvaltı sofram bu bölgeye has çok lezzetli bir esmer ekmek, kaymak, fazlaca sütle bezenmişti; hizmetkârım için çorba vb. getirildi ve onlar altı kişi kahvaltı ettiler: bu misafirperverlik alışkanlıktan veya dini zorunluluğun zamanla alışkanlığa dönüşmesinden kaynaklanıyordu” (Fellows, 1852:105). Burada Fellows'un gözlemi aslında tam da anlatılmak istenendir. Dini öğretiler, zamanla inananlarının hayatını şekillendiren öğelerdir.

Avrupa'nın Osmanlı Devleti'ne olan ilgisinin başlıca sebebi İslam değildir elbette. Daha önce de bahsedildiği üzere 19. yüzyıl, 1792 - 1922 yılları arasında Osmanlı Devleti için "dağılma dönemi" olarak adlandırılan dönemde yer almaktadır. Bu dönem, Osmanlı Devleti'nin bahse konu "dağglma"dan kurtulmanın yollarını arayarak geçirdiği bir süreçtir ve Osmanlı, ayakta kalabilmek için her türlü tavizi verebilen, dolayısıyla da uluslararası itibarını her geçen gün daha da kaybeden bir devlet halini almıș bulunmaktadır. Bu dönemde șahsi meraklarıyla veya çeșitli kurum ve kuruluşların maddi ve manevi destekleriyle gelen gezginlerin yanı sıra, Osmanlı topraklarına görevli olarak Avrupalı pek çok din adamı, eğitmen, devlet adamı veya asker de gelmiştir. Osmanlı'nın zor zamanlarındaki itibarının kaybı, bazı gezginlerin yazılarında açıkça belirtilmese dahi hissedilmektedir. Yabancı kazı ekiplerine kazı izni verilmesi ise, bu topraklara olan arkeolojik ilgiyi had safhaya çıkarmıştır. Ev sahipliği ettiği medeniyetler açısından bakıldığında, Küçük Asya ${ }^{2}$ olarak da tabir edilen Anadolu için söylenegelen "Medeniyetler Beşiğì" ifadesi hiç de abartılı değildir. Yunan-Roma Medeniyetlerinin Kurulu olduğu Batı Anadolu da bu ilgiden nasibini almıştır ve gezginlerin pek çoğu arkeolojik temelli seyahatnamelerinin satır aralarında Osmanlı dünyası izlenimlerine yer vermektedir. Tüm bu dürtülere ek olarak, Avrupalı gezginleri Osmanlı topraklarına çeken Oryantalizmin mistik cazibesini de göz ardı etmemek gerekmektedir.

\footnotetext{
${ }^{1}$ Charles Fellows (1799 - 1860): İngiltere Nottingham'da doğmuş arkeolog ve kâşiftir. Anadolu'da, özellikle de Likya'da yaptığı keşiflerle tanınır. Helenistik Dönem öncesine ait pek çok antik kenti günışığına çıkaran Fellows; Türkiye seyahati boyunca İzmir, Bergama, Assos, Bursa, İznik, İstanbul, Kütahya, Sagalossos, Selge, Antalya, Perge, Aspendos, Side gibi birçok şehirden geçmiştir. Faselis'e deniz yoluyla geçiş oradan da Likya'nın eski başkenti olan Ksantos şehrini Patara ve Tlos şehirlerini de bulmuştur. Ardından Karya, Milas, Efes gibi birçok tarihi şehri ziyaret etmiştir. British Museum tarafından desteklenen Fellows'un Likya mimari kalıntı ve heykellerini İngiltere'ye götürmesine yardımcı olacak bir ferman çıkarıldı. Ferman; 1842 yılında, Fellows'un bölgeye yapmakta olduğu üçüncü gezisi sırasında çıktı. Bu yılın sonunda Fellows, Ksantos'tan British Museum'a yetmiş sekiz sandık dolusu Likya heykeline ve çok sayıda mimari eser ulaştırmıştır. Buna ek olarak 1844 yılında yirmi yedi sandık dolusu yunan mezar heykelini de Londra'ya taşımıştır (http://www.oac.cdlib.org/ Er. Tar.: 18/04/2014).

${ }^{2}$ Küçük Asya, aslen Anadolu'ya verilen bir ad olmakla birlikte; bu tabirin kimi yazarlarca Batı Anadolu'ya ithafen kullanıldığı görülmektedir.
} 
2. 19. YÜZYILDA AYDIN VE ÇEVRESINE GELMIŞ GEZGINLER

\begin{tabular}{|c|c|c|c|}
\hline Gezginin Adı & $\begin{array}{c}\text { Gezginin } \\
\text { Yaşadığı } \\
\text { Yıllar }\end{array}$ & $\begin{array}{l}\text { Genel Olarak } \\
\text { Gezdiği Yerler }\end{array}$ & $\begin{array}{c}\text { Genel Olarak Anadolu'da } \\
\text { Gezdiği Yerler }\end{array}$ \\
\hline Richard Chandler & $1738-1810$ & İyonya ve Yunanistan & $\begin{array}{l}\text { İzmir, Aydın, Kuşadası, } \\
\text { Denizli, Çanakkale çevresi }\end{array}$ \\
\hline Robert Walsh & $1772-1852$ & Türkiye ve Asya & $\begin{array}{l}\text { İstanbul, Edirne, } \\
\text { İzmir, Aydın, Manisa }\end{array}$ \\
\hline $\begin{array}{l}\text { William Martin } \\
\text { Leake }\end{array}$ & $1777-1860$ & Arnavutluk ve Mora & Küçük Asya \\
\hline $\begin{array}{l}\text { Francis Vyvyan Jago } \\
\text { Arundell }\end{array}$ & $1780-1846$ & İzmir & Psidia'daki Antioch \\
\hline William Turner & $1792-1867$ & & İstanbul \\
\hline Charles Fellows & $1799-1860$ & Anadolu & $\begin{array}{l}\text { İzmir, Bergama, Assos, } \\
\text { Bursa, İznik, İstanbul, } \\
\text { Kütahya, Sagalossos, } \\
\text { Selge, } \\
\text { Antalya, Perge, Aspendos, } \\
\text { Side }\end{array}$ \\
\hline $\begin{array}{l}\text { George Thomas } \\
\text { Keppel }\end{array}$ & $1799-1891$ & $\begin{array}{l}\text { Babil, Tahran, Bakü, } \\
\text { Astrakan, Moskova, } \\
\text { St. Petersburg }\end{array}$ & İstanbul, Edirne, Balkanlar \\
\hline William Knight & Bilinmiyor & $\begin{array}{l}\text { Türkiye, Yunanistan, } \\
\text { Toskana }\end{array}$ & Anadolu \\
\hline $\begin{array}{l}\text { Charles Felix-Marie } \\
\text { Texier }\end{array}$ & $1802-1871$ & Anadolu & Hattuşaş \\
\hline $\begin{array}{l}\text { William John } \\
\text { Hamilton }\end{array}$ & $1805-1867$ & $\begin{array}{l}\text { Ermenistan ve Küçük } \\
\text { Asya }\end{array}$ & Anadolu \\
\hline $\begin{array}{l}\text { Hugh Edwin } \\
\text { Strickland }\end{array}$ & $1811-1853$ & Fransa ve İtalya & Anadolu’nun Batı Kıyıları \\
\hline Carl von Scherzer & $1821-1903$ & $\begin{array}{l}\text { İzmir, Leipzig, } \\
\text { Cenova }\end{array}$ & İzmir \\
\hline $\begin{array}{l}\text { Charles Thomas } \\
\text { Newton }\end{array}$ & $1816-1894$ & Midilli, Rodos, Roma & Bodrum, Knidos, Didim \\
\hline Hans Barth & $1862-1928$ & Anadolu & İzmir \\
\hline
\end{tabular}

Tablo 1 - Aydın ve çevresine gelmiş gezginler, yaşadıkları yıllar ve gezdikleri yerler 


\section{19. YÜZYILDA AYDIN VE ÇEVRESINE GELMIŞ GEZGINLERİN GÖZLEM VE IZLENIMLERI}

İlkçağlardan günümüze tarihin her döneminde önemli bir merkez olma özelliği taşıyan, birçok uygarlığa ev sahipliği yapmış, engin bir hazine konumundaki Büyük Menderes Ovası'nın önde gelen yerleşim birimlerinden antik dönemin Tralles'i, Beylikler Dönemi'nin Aydıneli'si, Osmanlıların Güzelhisar-ı Aydın'ı veya Aydın Güzelhisarı, her dönemde seyyahların ilgi odağı olmuştur. Aydın yalnız bir kent olarak gelişme göstermemiştir; aynı zamanda Osmanlı idari yapılanmasında Aydın Eyaleti olarak adlandırılan Saruhan, Aydın ve Sığla sancaklarını içine alan idari birimin merkezidir. Ancak 19. yüzyılın ikinci yarısında yaşanan değişim ve dönüşümün etkisiyle eyalet merkezi olma konumunu İzmir'e kaptırmış olsa da Aydın Vilayeti tabiriyle yalnız adını devam ettirmekle kalmamış, vilayetin beş sancağından biri olan Aydın Sancağı'nın merkezi olma vasfını da korumuştur. ${ }^{3}$ Her dönemde olduğu gibi 19. yüzyılda da Aydın ve çevresini ziyaret etmiş olan seyyahlar; bölgenin yönetimi ve yöneticileri, önde gelen aileleri, nüfusu, halk1, gelenek ve görenekleri gibi bir birçok konuda arşiv malzemelerine yansımayan, resmi kayıtlarda bulunması imkânsız olan sıradan halkın günlük yaşamlarına ilişkin değerli bilgiler sunmuştur.

Seyahatnamelerde Aydın ilinden Aydın ve Güzelhisar olarak bahsedilmektedir. Bunlardan "Aidin" ismi şehre yeni verilmiş bir isim olarak anılır ve henüz pek sık kullanılmamaktadır. Bununla birlikte, söz konusu isimlerin pek çok farklı şekilde yazıldığ 1 görülmektedir: Guzel-Hissar, Goozel-hissa, Ghulhissar, Aidin ve Idin.

\subsection{Nüfus}

19. yüzyılda çeşitli sebeplerle Batı Anadolu'ya gelmiş olan gezginler çoğu zaman bölge illerinin veya köylerinin büyüklüğü konusunda okuyucuda bir algı oluşturmak ve farklı milletlerin oluşturduğu çeşitliliğe dikkat çekmek amacıyla, bir kente veya köye vardıklarında önce sayısal veriler ve bu sayıların milliyetlere göre dă̆glımını konu alırlar. Örneğin; 19. yüzyıl başlarında bölgeye gelen ilk gezginlerden Robert Walsh ${ }^{4}$, Güzelhisar kasabasının; Juvenal'in Romalıları baştan çıkarmak için kadınlarını göndermekle damgaladığı antik Tralles olduğundan bahseder. Walsh'un tespitince Güzelhisar ili bu tarihlerde yaklaşık elli bin kişilik büyük bir nüfusu barındırmakta; burada Yahudilerin on sinagogu, Rum ve Ermeni Hiristiyanlarının ise iki kilisesi bulunmaktadır (Wilson,

\footnotetext{
3 19. yüzyılda Aydın Vilayeti İzmir, Aydın, Saruhan (Manisa) ve Menteşe (Menteşe) sancaklarını kapsıyordu. II. Abdülhamit döneminin sonuna doğru Denizli Sancağı'nın da bu vilayete katıldığı anlaşılmaktadır (Aysun Sarıbey Haykıran, XIX. Yüzyıl Aydın Kent Tarihi Bibliyografyası, Türkiye Cumhuriyeti'nin 90. Yılına Armağan, Basılmamış Kitap Bölümü).

${ }^{4}$ Robert Walsh (1772 - 1852): Din adamı, tarihçi, yazar, hekim kimlikleriyle tanınan İrlandalı Walsh; James Whitelaw ve John Burton'un araştırmalarıyla katkıda bulunduğu, iki cilt halinde yayımlanan History of the City of Dublin (Dublin Tarihi - 1815) isimli eseriyle ünlüdür. 1820 yılında the Royal College, Aberdeen'den tıp doktoru ve Trinity College, Dublin'den de hukuk doktoru diploması almasını takiben İstanbul'da İngiliz Büyükelçiliği için din görevlisi olmayı kabul etti ve görevde kaldığı yıllar boyunca Türkiye ve Asya'nın diğer bölümlerine kapsamlı keşif gezileri düzenledi. Tıp derecesi de olduğundan, kıtanın bazı uzak bölgelerinde birkaç kez hekim kimliğini de kullanmıştır. İstanbul'dan St. Petersburg'a görevlendirildi ve 1828 yılında Rio de Janerio'ya atandı. Brezilya'daki yaygın köle ticareti araştırmaları sonucunda Köleliğin Kaldırılması Derneği'ne üye oldu. 1831 yılında tekrar İngiltere'ye dönen Walsh, tekrar İstanbul'a gönderildi. 1835 yılında doğduğu yer olan İrlanda'ya kesin dönüş yaptı. Türkiye'de bulunduğu süre boyunca İstanbul, Edirne, İzmir, Aydın, Manisa ve çevrelerinde bulunarak gözlemlerini çeşitli eserlerde paylaşmıştır (http://www.oxforddnb.com/ Er. Tar.: 18.04.2014).
} 
2006:206). Yolu 1830'lu yıllarda Küçük Asya'ya düşen Charles Texier ${ }^{5}$ de Aydın iline gelmiş ve şehre dair gözlemlerini aktarmıştır. Texier, geçen süre içerisinde Aydın nüfusunun yaklaşık olarak altmış bin kadar olduğunu belirtir. Toplam hane sayısının on iki bini bulduğunu ve bu sayıdan dört yüze yakınının Rumlara ait olduğunu ekler (Texier, 2002:114).

\subsection{Türk Halkı}

Batı Anadolu'ya gelen tüm gezginler, kendi kültürlerine ve halklarına çok yabancı olan Türk kültürü ve Türk halkına dair gözlemlerine değinmeden etmemişlerdir. Türk insanından genel olarak dürüst, misafirperver, yabancılara meraklı olarak söz eden gezginlerin buluştukları ortak nokta, onda gördükleri, sanata ve tarihe aşırı duyarsızlıklarıdır. Medeniyetler Beşiği’nde yaşayıp, her yanlarında görmeye alışık oldukları tarihi eserlere sıradan taşlar olarak bakan dönem Türk’ü pek çok gezginin eleştirisine uğramıştır. Onlara göre Türk ve Müslüman halk tarafından inşa edilmeyen her yapıyı yıkmakta hiçbir sakınca görmeyen Türk insanı; bu yapılardan aldıkları mermer ve sütunları kendi binalarının veya camilerinin yapımında kullanmayı günlük hayatlarının olağan bir eylemi olarak görmektedir.

Keppel $^{6}$ Türk halkının sosyolojik özelliklerinden ziyade, İslam'a bağl1lıklarını ve dine olan bu adanmışlıklarından ötürü de, aynı zamanda halife olan Padişah'a olan sadakati dile getirmektedir. Söz

\footnotetext{
${ }^{5}$ Charles Felix-Marie Texier (1802 - 1871): Paris Güzel Sanatlar Yüksek Okulunu bitirmiş; Fransız Bilimler Akademisi ve Paris Arkeoloji Enstitüsü üyelikleri yapmıştır. Bayındırlık İșleri Müfettişliği görevi esnasında Fransız Hükümeti tarafından Anadolu'ya gönderilmiştir. İlki 1833 ve ikincisi 1843 y1lında olmak üzere Anadolu'da yıllarca süren seyahat ve incelemeleri sırasında yurdumuzun çok büyük bir kısmını baştanbaşa gezip dolaşmış, kazılar yapmış, araştırmalarda bulunmuş ve bütün bu çalışmalarının sonuçlarını yayınlamıştır. Bu eserin, Türkiye Arkeolojisi için belki de en orijinal kısmı, topografik haritasını çıkartıp birçok yerini resimlediği Hititlerin başşehri Hattuşaş (Boğazköy) ile buranın açık hava tapınağı olan Yazılıkaya'yı bulmuş ve dünyaya tanıtmış olmasıdır. Gezip dolaştığı yerlerde sadece antik devirlere ait değil, daha sonraki devirlere ait (Selçuklu, Beylikler, Osmanlı vb.) de önemli şehirlerin, yapı ve anıtların çizimlerini yapmış, uzmanlar tarafından gravürlerle durumlarını tespit etmiştir. Bunlarla da yetinmemiş, Anadolu'nun jeolojik yapısı, coğrafî özellikleri, yer altı ve yer üstü kaynakları ve kültür merkezlerinin tarihî ve o günkü halkın etnik, demografik, kültürel, ekonomik vb. durumu hakkında bilgi vermiş, gözlemlerini aktarmıştı. Texier, ilmî merak ve özel ilgileri ile Osmanlı Devletinin hâkim olduğu topraklarda seyahat ve araştırma yapmak isteyenleri caydırıcı, kasıtllı ve yanlış propaganda ve görüşleri, kendi çalışmalarına ve görüp yaşadıklarına dayanarak, gerek basın-yayın yoluyla, gerekse aydınlatıcı konferanslarıyla, etkisiz kılmak için de gayret sarf etmiştir. Dönem Türkiye'si üzerine detaylı gözlem ve araştırmalarını aktardığı "Asie Mineure, Description Géographique, Historique et Archéologique des Provinces et des Villes de la Chersonnése d'Asie" adlı eseri, Ali Suat tarafından "Küçük Asya - Coğrafyası, Tarihi ve Arkeolojisi”" adıyla Türkçe'ye çevrilmiştir (www.doguedebiyati.com/ Er. Tar.: 18/14/2014) .

${ }^{6}$ George Thomas Keppel (1799 - 1891): Altınc1 Albemarle Kontu George Thomas Keppel, 1799 y1lında Marylebone - İngiltere'de dünyaya geldi. Soylu bir aileye mensup olan Keppel, Westminster School'da ilköğrenimini gördü. $\mathrm{O}$ yıllarda herhangi bir meslek edinemeyecek kadar başarısız olduğu iddia edilmekle birlikte, ailesinin nüfuzu sayesinde orduda görevlendirildi ve Waterloo Savaşı'na katıldı. 1815 yılının sonunda ordusuyla birlikte ülkesine dönmesini takiben, askeri görevi sebebiyle 1821 yllında teğmen olarak Hindistan'a gönderildi. 1823 yılında ülkesine dönüşü esnasında Babil ve Tahran tarihi kalıntılarını ziyarette bulundu ve Bakü, Astrakan, Moskova, St. Petersburg üzerinden İngiltere’ye ulaştı. Bu yolculuğu anlattığı ilginç bir günlük yayınladı. Askeri rütbesi yükselmeye devam ederken, 1829 yılında Osmanlı - Rus Savaşı'nı yerinde görmek için bir İngiliz filosuyla Türk sularına girdi. İstanbul ve Edirne'yi ziyaret ederek Balkanlara geçti. 1832 - 1847 yılları arasında kendini İngiltere'de siyasete adadı. Kardeşi Beşinci Kont Augustus Frederick'in ölümüyle 1852 yılında onun yerine geçti. Westminster School'un mütevelli heyetinde görevlendirildi. Londra'da bu kadar uzun süre tanınan ve popüler olan pek az kişiden biriydi. Waterloo Savaşı'nın her yıldönümünde resepsiyon düzenledi. 1891 yllinda Londra'da hayata veda eden Albemarle'nin yazılı eserleri "Personal Narrative of a Journey from India to England ...(Hindistan'dan İngiltere'ye Yolculuk Üzerine Kişisel Anlat1 - 1825), 'Narrative of a Journey across the Balkans and a Visit to Newly Discovered Ruins in Asia Minor (Balkanlara Yolculuk ve Küçük Asya Harabelerine Ziyaret Üzerine Anlatı - 1830), Memoirs of the Marquis of Rockingham and his Contemporaries (Rockingham Markizi ve Dönemine Ait Hatıralar - 1852), Fifty Years of My Life (Hayatımın Elli Yılı - 1876)" başlıklarını taşır (http://www.historyhome.co.uk/ Er. Tar.: 18/04/2014).
} 
konusu sadakati Keppel şu şekilde tasvir eder: "Ne zaman Osmanl yönetiminin sürekliliği düşünülse, İslam dinine olan bağl da göz önünde bulundurulmalıdır. Osmanlı'nın sultanına bağlllı̆̆l imparatorun geçici otoritesinden ziyade onun halife olarak sahip olduğu ruhani kapasitesidir. Bu sebeple onun doğru bir Müslüman olarak tanınmasını baltalayacak olan herhangi bir etken, aynı zamanda monarşisi için de büyük tehlike oluşturacaktır. Montesquieu'nun da dediği gibi "Müslüman ülkelerde insanların yöneticilerine olan şaşırtıcı saygıları kısmen dinden gelir". Başka bir yerde ise aynı yazar şöyle der: "Bazı açılardan Türk yasalarını değiştiren dindir. Devletin azametiyle hiçbir bağı olmayan tebaa, ona dinin gücü ve ilkeleriyle bağlanır” (Keppel, 1831: 82).

Türk insanının dürüstlüğü ise dikkat çeken başka bir konudur. Aslında bu özelliğin, İslam'ın getirdiği bir alışkanlıktan, haram ve günah olgularından kaynaklandığını söylemek yanlış olmaz. Keppel, Türklerin dürüstlügüne dair şahit olduğu bir hikâyeyi şu şekilde kaleme alır: "1828 yılının kış mevsiminde bir Türk postacl, yanında yüklü miktar sikkeyle uzak bir bölgeye gönderildi. Para çantalar içerisindeydi. Çantalar, daha önce de bahsettiğim üzere, herhangi bir tutanak olmaksızın postacıya verildi. Bu adam yolculuğundan dönüşte, bir Fransız evinde kendisinden on beş bin kuruş (yaklaşık iki yüz elli pound) istendi. Bu talebe karşı çıkmadı ve hemen "şüphesiz ki çantayı yolda kaybetti ve bu yüzden bu parayı biriktirir biriktirmez sana ödeyeceğim” dedi. Sakin şekilde düşündükten sonra ayn yoldan geri döndü ve parayı bir Müslüman'ın bulması halinde kendisine geri vereceğinden emindi. Neredeyse bütün yolu tekrar gitti ve çaresiz bir şekilde, yolculuğu esnasında birkaç dakika dinlendiğini hatırladığı bir kahvehaneye vardı. Kapıdaki Zeybek kahveci kendisine şöyle bağırdl: "geçen geldiğinde içinde - galiba - altın olan bir çanta unutmuşsun; koyduğun yerde duruyor". Postacı içeri girdi; bir Türk kahvehanesine gelen pek çok kişinin rahatllkla alabileceği şekilde ortada durmasına răgmen dokunulmamış görünen çantasını buldu” (Keppel, 1831:291).

Küçük Asya'ya 1838, 1840 ve 1841 y1llarında olmak üzere toplam üç kere gelen Fellows, Türk insanına yönelik gözlemlerini en detaylı sunmuş gezgindir. Osmanlı topraklarına ilk geldiğinde gezginin Türker'e olan önyargısını dile getirmekten çekinmediğini ve her firsatta vurguladı̆̆ını söylemek yanlış olmaz. Örneğin Fellows, Türklerden genel olarak -görünüş veya mizaç anlamlarındahoşlanmadığını açıkça dile getirir. Türk çocuklarının hala önyargılarla büyütüldüğünden, bir yabancı gördügünde arkasından "Frenk, Frenk Köpeği” ve benzer hakaretlerde bulunan, yabanciya vurup kaçan çocuklardan dert yanar. Çocuklardaki bu önyargı ne kadar fazlaysa, yetişkin erkeklerde var olagelen aynı önyargıların giderek azalmaya başladığının da altını çizer Fellows. İslam dini resim yapmayı yasaklarken, yaptığı resme ilgiyle yaklaşan Türk erkeklerinin ilgi ve memnuniyetle kendisini izlediğini belirtir (Fellows, 1852:6). Türk insanının yabancılara olan merakı da bazı zamanlarda gezgini öyle bunaltır ki; yemek yerken, giyinirken, günlük işlerini yaparken kendisini dikkat ve merakla izleyen insanlardan bunalan Fellows, çareyi kendini yardımcısı aracılığıyla huysuz ve konuşmaya gelmeyen bir insan olarak tanıtmakta bulur. Fellows, Türk insanının hiçbir zaman yalnız olmayacak kadar sosyal olduğuna da değinir (Fellows, 1852:188). Bununla birlikte, ona göre tarihi eserlere karşı son derece duyarsız olan Türkler, yabancılara olan merakından dolayı her şeyi kurcalamaya ve sorgulamaya da meyillidir (Fellows, 1852: 39).

Fellows, Türklerin bu bölgeye dair hiçbir geleneği olmadığından, tahmin edilebileceğinden çok daha umursamaz olduklarından ve bilmemekle kalmayıp, öğrenmemeye de kararlı görünen tutumlarından söz eder. Ona göre Türkler, kendileri tarafından inşa edilmeyen her kalıntıya "Eski Kale" deyivermektedirler ve bazı yapıların kullanımına dair hiçbir fikre ve meraka sahip değildirler (Fellows, 1852: 39). Gezgin bunun sebebini Türklerin bu topraklarda sadece işgalci olarak bulunduklarına ve bu topraklarda kendilerine özgü herhangi bir gelenek bulunmadığına bağlar (Fellows, 1852: 25). Aynı zamanda hemen her yerde sütunlar, büstler, pervazlar ve saçakliklar görmek mümkün olmasına rağmen, dini inançlarından dolayı Türk insanı bu büstlerin uzuvlarını -kendi deyişiyle vicdanlarını rahatlatmak amaciyla- yok etmektedirler (Fellows, 1852:8). 
Fellows'un da bahsettiği üzere, Türk halk1 tarihi kalıntılara kendi kökenlerine ait olmadığ1 düşüncesiyle sahip çıkmamıştır. Başka bir medeniyetin izlerini taşıyan bu kalıntıları, cami, bina veya mezar taş1 olarak kullanmakta herhangi bir sakınca da görmemiştir. Bununla birlikte, söz konusu halkın çoğunda antik yerleşim yerlerinde buldukları pek çok madeni para, heykel parçası veya gereç bulunmaktadır. Fakat söylenen o ki, çoğu Türk insanı bu değerli parçaları tarihi değerinden ziyade, bir yabancıya -kendince- yüksek bir fiyat karşılığında satmak için elinde bulundurmaktadır. Söz konusu alışverişler yerel halka oldukça karlı görünse de, tarihi değerinin farkında olan bir Avrupalı için aslında komik meblağlardan bahsedilmektedir. Fellows, bahse konu bir alışverişine dair izlenimlerini şu şekilde paylaşmaktadır: "Çocukların oyun alanlarında veya tarihi duvarların etrafinda bulunabilen madeni para veya eski parçalardan istiyordum. Belki bir Frenk gelip bu tür şeylere biraz para verir düşüncesiyle, burada herkesin kendisine ait bir hazinesi vardl. Satın aldı̆̆ımı şeylerin değeri veya kullanımına ilişkin hiçbir şey bilmiyorlard. Beşşiline güzel bir Yunan heykeli ve sekiz şiline iki bronz vazo satıldiğını duydum ve Türkler ne kadar büyük paralar kazandıklarıyla böbürleniyorlardı. Hizmetkârım, her biri ü̧ farthing' $e^{7}$ otuz - kırk Yunan madeni parası satın aldl; ben de uygun fiyata bir heykel ayă̆ı ve birkaç bronz kapı kolu aldım” (Fellows, 1852:104).

Sanat ve tarihe olan ilgisizlik ve duyarsızlıklarıyla Osmanlı topraklarındaki Avrupalıların tepkisini çekmiş olan Türk insanını bunu yapmaktan alıkoyabilecek tek şeyin yine din olduğunu belirtir Fellows: "Şimdiye kadar "eski kale" olarak adlandırdı̆̆ tarihi kalıntıları gizli bir hazineye bağlamayan bir Türk görmedim; Türklerin inancına göre - şayet anlayabilselerdi - her yazı bir hazineden bahsediyordu ve her mağara tarihi bir altın deposuna çıkıyordu; fakat çocuk hikayeleri gibi bu hikayeler de Türklerin karakteristik ahlaklarından izler taşımaktaydl; hazineyi almak isteyen biri buraya girerse, çalmak istediği şeyi geri bırakana kadar burada hapis kalır ve karanlık kemerler arasında kaybolur; geri bıraktıktan sonraysa açık kapıdan elleri boş olarak çıkabilirdi. Bir keresinde bir Yahudi'nin bir mağaraya girdiği ve başına aynen bahsedilenlerin geldiği söylenmekte, fakat bu ders Türkleri aynı eylemi yapmaktan alıkoymuş bulunuyor. Ülkedeki pek çok sıcak su kaynă̆ı ve volkanik gazlı alevler dürüst bir çobanın etini seve seve pişirecekken, çalıntı olan hiçbir şey bu yerlerde pişirilemez. Ne kadar çocukça da görünse, bu saf basitliğin kaybolmasına neredeyse üzülebilirim" (Fellows, 1852:278).

"Bu sabah odamız madeni para ve hazineler getiren Türklerle oldukça kalabalıktı, bunların bazıları ise oldukça gülünçtü - kullanımlarını bilmedikleri için bu insanlara değerli gözüken modern Rus ve Yunan madeni paralarl, düğmeler, teneke parçaları, bir kaşığın bir bölümü... bugün bir Türkün oldukça dikkatli davranışı şahsıma oldukça gülünç geldi: elinde görmem gereken mermer bir figürün başı olduğunu söyledi; epey bir gecikmeden sonra, bazı genç askerlere kıyafet dikmek için iş gezisinde olan, şehre girerken gördügümüz Rus bir terzi geldi, yıpranmıs küçük kafa kaidesini odama getirdi ve buna kendim paha biçebileceğimi belirtti. Soruşturmam sonrasında putlarla ilgilenmenin ve böyle bir insan temsiline bakmanın Müslümanlara Peygamber tarafindan yasaklandığını öğrendim; heykelin sahibi bu sebeple bana fiyat belirtmemişti. Bu kuralın sıkı şekilde takip edilmesi sanatın gelişmesine sürekli bir engel teşkil etmekteydi; fakat aynı kural, Yahudilerde de olmasina rağmen, onları bu sanatı icra etmelerine engel teşkil etmemekteydi. Hatta putperestlik benzeri eylemler ilk Hıristiyan kilisesinde de vardl; sadece Peygamber, putperestlik ve benzeri her türlü ibadet yerini temizlemeye yetmistit” (Fellows, 1852:283).

Fellows, Türklere karşı yukarıda da bahsedilen önyargısına ilişkin girizgâhı aslında seyahatnamesinin önsözünde yapmış bulunmaktadır. Gezgin, günlüğünün önsözünde bu topraklara ilk gelişinde Rumlar lehinde ve aynı derecede Türkler aleyhinde sabit fikirleri olduğundan bahseder, fakat ona göre bu insanlarla, dinleri hariç her türlü dayatmadan sıyrıldıklarında kurduğu kişisel samimiyet sonucunda

\footnotetext{
${ }^{7}$ Farthing: Çeyrek penny'den oluşan İngiliz para birimi.
} 
Türk karakteri hakkındaki olumsuz görüşleri yavaş yavaş ortadan kalkmıştır ve günlüğünün sayfalarını çevirdikçe, Türkler aleyhindeki keskin söylemlerin zaman içerisinde yumuşadığını söylemek mümkündür (Fellows, 1852:vii). "Şu anda Türklere olan hislerim buraya ilk varışımda onlara karşı takındı̆̆ım önyargllı tavirdan ne kadar farklı! Hal, tavır, karakter ve bir o kadar da giysilerini sadece kabullenmekle kalmadım, fakat samimi şekilde bağlandım da; çünkü burada insanlardaki doğruluk, dürüstlük ve kibarlı gibi en saygıdeğer nitelikleri bulmak için çok aramaya gerek yok" (Fellows, 1852:221).

Fellows Türk insanının içine işlemiş olan başlıca özellikleri olarak dinlerine olan bağlılıklarını gösterir. Ona göre, ahlak kurallarını olduğu kadar, hukuku da din oluşturmakta ve dünyevi iş ve uğraşlarla kesintiye uğramak yerine, günlük hayatın ve hayatın her anının ayrılmaz bir parçası halini almış bulunmaktadır. İbadet evrenseldir, bir mekâna bağlı değildir - camide olduğu gibi, bir odada da ibadet etmek mümkündür. Herkes kendi inancını bir aracı olmaksızın, mutlak bir yalınlıkla ve her türlü gösterişten uzak olarak, kendi yaşamaktadır. İnsanların karakterini, alışkanlık, gelenek, tutum, sağlık ve tüm yaşamlarını da dinin şekillendirdiğine değinmektedir Fellows. Bazı şeylerin neden yapıldığına dair sorularına dinin bu şekilde emrettiğine yönelik sürekli aldığı cevaplarla dinin günlük hayat ve görevleri düzenlediğini görmektedir. Din ve hukuk birdir, okulda çocuklara ikisi birlikte öğretilir ve bu şekilde öğretilen görevlerin ihlalinde Sultan'ın cezalandırma yetkisi kesindir ve ceza kati surette uygulanacaktır (Fellows, 1852:221). Fellows'un Türk insanı hakkındaki gözlemlerini kendi anlatımıyla sunmak doğru olacaktır: "Buradaki bir yabancı veya misafirin ilk dikkatini çekecek olan özellik misafirperverliktir. Misafir veya bir yabanclya gerçekten misafirperverlikle yaklaşıllr. Bu özellik Paşadan dăg arasinda çadırda yaşayan köylüye kadar her rütbeden kişi tarafindan, hiçbir karşıllk beklemeksizin tarafimda gösterildi. Hiçbir soru sorulmadl, millet - din - zenginlik - fakirlik düşünülmedi; “yabancıyı doyur” evrensel bir kurald. Sonra dürüstlükleri göze çarpar. Yoldan geçenler olmasına ve merakla eşyalarımızı incelemelerine rağmen; eyer, at başlı̆̆l, mutfak gereçleri ve içeride lazım olmayan her şeyi, hizmetkârımla bir şey kaybetme korkusu olmadan kaldiğımız çadırımın dişında bırakma alışkanlığım vardı. Bir tel bile kaybetmedim. Bunu fark ederek hizmetkârıma belirttiğimde bir Rum, dinlerinin çalmayı yasakladı̆̆ bahanesini gösterdi. Burada çalınabilecek pek çok şey vardı - örneğin ülkenin madeni paralarlyla süslenmiş kadın ve çocuk giysileri - fakat dinleri "çalmayacaksinız" emrini buyurmaktayd v ve bu emir evrensel itaat görmekteydi. Dürüstlüğün ikiz kardeşi olan doğruluk da burada bir hayli göze çarpıyor; burada bir Rum yine mahcup şekilde "Müslümanlar yalan söylemeye cesaret edemez, dinleri bunu yasaklar" deyiveriyor. Evladın babasina hizmet etmesini bir ayrlcallk kllan ulusal gelenek de, ebeveynleri onore etmeyi bir görev haline getirmekte. Aileler ve diğer yabancılar arasında gördüğüm her ilişki ve ortamda birbirlerine karşı sevgi ve nezaket gösterdiklerini fark ettim: samimiyetleri şüpheyi ortadan kaldırıyor ve doğruluk ve dürüstlükleri her işlerinde açıklı̆̆ beraberinde getiriyor. Yahudi yasasında olduğu gibi din, paradan faiz almayı yasakliyor. Para ödünç vermekle ilgili eylemlerden kaçınıyorlar. Bu sebeple diğer milletler, genellikle de Ermeniler, burada banker görevini üstlenmiş görünmekteler. Dini inançlarından dolayı İlahi Iradeye o kadar çok güveniyorlar ki bu, kaderci yaklaşımın biraz yanlış anlaşılmasına yol açabiliyor. Kötülükleri engellemek için ellerinden geleni yapıyorlar: yangın söndürmek için nasıl çabaladıklarını gördüm, benden çok kere ilaç istediler ve hastalıklarına baktırmak için oldukça istekliydiler; fakat bir yangın söndürülemezse "Allah büyüktür!' diyorlar veya bir hastalı ölümle sonuçlanırsa, bu bir evlat veya anne - baba dahi olsa - gergin gözler kalbin hala attığını söylese de, naaş mezara aynı teslimiyetçi yaklaşımla götürülüyor, "Allah büyüktür ve bağışlayıcıdır”.

İslam'ın çok eşliliğe izin vermesi, dinin uzmanlarının ahlaki özelliklerine getirilmiş ciddi yüklerden biridir. Kanun pek çok kadına izin verse de, bu bireyin seçimidir. Dağlardaki çadırında tek bir hanımıyla yaşayan ve eşine bir Hıristiyan ülkesindeki bir köylü kadar bağll görünen binlerce Türk 
gördüm. Birden çok kadının bir arada bulunması hali lüksün ortasındaki zengin ve büyük saraylarda görünen bir durum. Bu insanlar ziyaret etmeden önce karakterlerinin gaddar olduğunu düşünüyordum; fakat buna dair kanıt bulmaktan çok uzak olmakla birlikte, bunun özellikle tam tersi olduklarını gördüm. Yük hayvanlarını cezalandırma şekilleri pek az bilinmekte: bir deve üzerindeki tek tutumları nezaket ve ödül ve devenin itaati de ayn şekilde tam. Avrupa'da kuşlar ve hayvanlarda korku olmaması bir Avrupalı için çok çarpıcıdır ve Türkleri bu ithamdan kurtarmaya yeterlidir.

Müslümanların şaraptan uzak durmaları belki de fiziksel olduğu kadar ahlaki sağlıklarından da kaynaklanmaktadır. Yukarıda bahsedilen kaideleri tehlikeye düşürecek aşırllıklar bu sebeple tamamen yasaklanmış durumda. Bu kanunun fiziksel sonucu da kötürümlerin dikkate değer derecede azlığı ve Türklerin hastalıklardan uzak olması olarak belirtilebilir; neredeyse tek hastalık sıklıkla görülen diş ağrısıdır. Görme engelliler hariç dilenci görmedim ve çok fakir görünen de pek az kişiye rast geldim. Insanların az saylda olan istekleri, durum ne olursa olsun, genellikle yeterince karşılanlyor. Afyon etkisinde hiçbir Türk görmedim ve sanırım bu uyarıcı sadece hovardaların alışkanlığı olarak süregelmekte" (Fellows, 1852:222 - 224).

Türk halkının üzerinde bulunduğu topraklarda var olmuş Antik Yunan medeniyetine ait, tarihe 1şık tutacak paha biçilmez kalıntılara olan ilgisiz ve bilgisizlikleri, Batı Anadolu'ya gelen Fellows gibi gezginlerin tümünün Türk halkına dair ortak olarak dikkat çektiği özelliktir. Hamilton ${ }^{8}$ da notlarıyla bu izlenimi -Fellows kadar sert olmasa da- destekler ve Pomoerium'da tiyatro yanındaki Türk köyüne bakan kısımdaki bütün yapıların bu antik kalıntılara yapılmış olan yağmalardan izler taşıdığını, yüksek duvarların tamamen bu muazzam taş ocağından alınan taş bloklardan oluştuğunu ve meşhur KervanKöprü civarındakiler gibi buranın etrafındaki mezarların da antik sanat eserleriyle dolu olduğunu ekler (Hamilton, 1842: 57). Texier ise Tralles Antik Kenti'ndeki anıtlarda bulunan küçük taşların -işe yaramayacağı düşüncesiyle- yerinde bırakıldığını, fakat büyük mermer taşlarının alınarak, Aydın camilerinin yapımında kullanıldığını belirtir. Texier'in deyişiyle Türkler, mermer parçalarını mezar yapmakta kullandıklarından, Tralles'in duvarlarında tek bir sütun kalmamıştır. Oysa Tralles'te aslen çok fazla sütun bulunmaktadır, bunun en büyük kanıtı da şehrin çevre yollarının üzerindeki kuyuların ağızlarındaki mermer bileziklerin, genellikle ortası oyulmuş sütun kaidelerinin parçaları olduğu savıdır (Texier, 2002:113).

Charles Thomas Newton", bir cümle arasında bu halkın "Türk tütününe uyumlu şekilde meditasyon yaparcasına" sigara içtiklerine dikkat çekmiştir. Bununla birlikte Rumlar ve Türkler arasında küçük

\footnotetext{
${ }^{8}$ William John Hamilton (1805 - 1867): İngiliz jeolog W. J. Hamilton, Wishaw - Lanarkshire'da doğmuştur. Öğrenimini Charterhouse ve Goettingen Üniversitesi'nde tamamlayan Hamilton, modern diller ve tarihe özel bir ilgi gösterdi. 1737 y1lında kurulan Alman Üniversitesi fen bilimleri üzerine kurulmuş olduğundan, Hamilton'ın çalışmaları bu alanları da içine aldı. 1827'de Üniversiteden ayrılan Hamilton Madrid ve kısa süre de Paris'te ataşe olarak görev yaptı ve 1829'da İngiltere'ye döndüğünde bilime olan ilgisi daha baskın çıkmaya başladı. Roderick Impey Murchinson ile jeoloji üzerine çalışan Hamilton, 1831'de Jeoloji Cemiyeti'ne katıldı. Murchison aracılığıyla tanıştırılan Hamilton ve Hugh Strickland, birlikte Levant'a jeolojik bir seyahate çıktı. Bu seyahatten sonra Hamilton yoluna Ermenistan ve Küçük Asya’ya doğru devam ederek dikkatli topografik gözlemlerde bulundu ve jeolojik ağırlıklı tam bir günlük tutmaya başladı. İki baskı halindeki, resimlerini yazarın çizdiği "Researches in Asia Minor, Pontus, and Armenia, with Some Account of Their Antiquities and Geology" (Tarihi Eserleri ve Jeolojisi Bakımından Küçük Asya Araştırmaları, Pontus ve Ermenistan - 1842) isimli eseri Kraliyet Coğrafya Cemiyeti'ne sunuldu ve kurucusu tarafından eser madalyaya layık görüldü. British Museum'a mutemet tayin edilen gezginin başlıca eseri Aegyptiaca 1809 yılında yayımlandı. Toskana'daki taşlar ve mineraller, Oberstein'ın taş ocakları ve Mayence Havzası'nın ve Hesse Cassel Bölgesi'nin jeolojisi gibi konularda makaleler de yayımladı. Fransa ve Belçika'ya pek çok keşif gezisi düzenleyen Hamilton, 1865 yılında cemiyete tekrar başkan seçildi. 1866 yılında görevden ayrılarak İngiltere'ye dönen Hamilton, aynı yıl hayata veda etti (http://www.amphilsoc.org/ Er. Tar.: 18/04/2014).

${ }^{9}$ Charles Thomas Newton (1816 - 1894): İngiliz arkeolog Charles Thomas Newton, Bodrum'daki Mausoleum ve Knidos kentinde ilk kazıları gerçekleştirmiştir. 1852'de Midilli Adası'nda, daha sonra Rodos Adası ve Roma'da konsolos olarak görev yapan Newton; bu dönemde Kalimnos Adası'yla Anadolu'da Bodrum
} 
bir kıyaslama yaparak, Türk insanının Rumların olabileceği gibi hayat dolu veya zeki olmamakla birlikte, en azından daha kültürlü olduklarına değinmiştir. Newton, karşılaştığı Türklerin yorgun bir yabancıyı yalnız bırakacak kadar halden anlayan insanlar olduklarından bahseder. Türkler buradaki Rum halkı gibi ellerini bir yabancının çantasına sokuşturmuyor, seyahat amacını araştırmıyor, yıllık kazanç veya kavasa ne kadar para verdiğini sormuyorlardı. Ne iltifat bekliyorlar, ne de fazlaca iltifat ediyorlardı. Misafirperverlikleri aşırı ilgi veya bunaltıcı müdahaleye dönüşmüyordu. Kısacası Newton, burada oldukça rahat olduğundan bahsetmektedir (Newton, 1865: 50). Newton seyahatnamesinin başka bir bölümünde, İngiltere'den gelen araç - gerecini incelemek için etrafinda toplanan Türkleri anlatır: "Yüklerimizi indirirken, İngiltere'den ithal ettiğimiz mükemmel araç - gereci incelemek üzere etrafimızda bir kalabalık oluştu. İstanbul ve birkaç büyük Türk şehri haricinde burada metalürji çok ihmal edilmiş ve hayli maliyetli olan demir genellikle Rusya'dan ithal edilmekteydi. Bu sebeple burada madenci kazmaları, levyeler ve tokmaklara duyulan hayranlık müthişti. Dövme demirden yapılmış tekerlekleri olan el arabası Britonlar zamanındaki arabalar gibi, Türk yollarında bile hızla ilerleyebilen yük arabalart; zihinlerine bilinmeyen ve gizemli mekanik güçler olarak zuhur eden palanga ve üçgenler karşısındaki hayranlıkları ise daha büyüktü. Her şey Marifet, Çok marifetti. ${ }^{10} \mathrm{Bu}$ kelime her türlü mekanik deha şaheseri için kullanılmaktaydı ve özellikle Frenk ismiyle özdeşleşmiş bir etiketti" (Newton, 1865: 69). Türk insanına bir süre sonra iş de veren Newton, düzgün davranıldığında Türklerin, olabildiğince zeki ve uyumlu işçiler olduklarından; denizciler kadar becerikli veya çabuk olmasalar da, azimlerinin hareketlerindeki yavaşlığ telafi ettiğinden bahsetmektedir. Sırtlarında ağır yükler taşımak konusunda çok güçlü olan Türklerin, İngilizler gibi kazmayı çok şiddetle vurmadıklarına, bunun da antik kalıntılar bulunduğunda önemli bir avantaj sağladığına dikkat çekmektedir (Newton, 1865: 70).

Türk insanının genel özelliklerine dair en detaylı gözlemlerini sunan gezgin Scherzer"11, dir: "Türk insanı suskun, ağırkanlı ve ciddidir; fakat akıllı oldukları gibi sağlıkl bir mantıkları vardır ve de iyi birer gözlemcidirler, ne yazlk ki bu özelliklerini günün rutin işlerinde kullanmaktadırlar. Bu nedenle vilayetin ticari yaşamında gözükmemektedirler... Türk insanı genel olarak dürüst, iyi niyetli, açık yürekli ve misafirperverdir; inanç konusunda tanındıklarının tam aksine Doğu'nun en hoşgörülü

(Halikarnassos), Knidos ve Didima'da kazı ve araştırmalar yaptı. 1861'de Londra'ya dönerek British Museum'daki Yunan ve Roma Sanatı Bölümü'nün ilk müdürü oldu. 1880-1888 arasında University College'da arkeoloji profesörü olarak görev yaptı. 1887'de Sir unvanı verildi. Newton, 1846 'da İngiliz diplomat Stratford de Redcliffe'in Bodrum Kalesi'nden British Museum'a götürdüğü kabartmalı frizlerden çok etkilendi. Bunların Halikarnassos'daki Mausoleum'a ait olduğunu düşündü. Midilli Adası'ndaki konsolosluk görevi sırasında 1852 ve 1855 yıllarında Bodrum Yarımadası'nın hemen yakınındaki Kalimnos Adası'nda araştırmalarda bulundu. 1856-1857 yıllarında dünyanın yedi harikasından biri sayılan Halikarnassos Mausoleumu'nda yaptı̆̆ kazıda Stratford'un ilk parçalarını British Museum'a götürdüğ̈̈ Amazon frizinin eksik parçalarını buldu. İÖ 350'de Karya Kralı Mausolus için karısı tarafindan yaptırılan bu anıtsal mezardaki çalışmalar, 1966'dan sonra Danimarkalı arkeolog Kristian Jeppesen başkanlığında sürdürüldü. Newton, Mausoleum'un çeşitli parçalarının yanı sıra, aralarında tanrıça Demeter'in oturan heykeli, Knidos'un anıtsal aslanı ve Didima kentindeki kutsal yola ait heykelleri de British Museum'a gönderdi. 1858-1859 yıllarında Datça Yarımadasındaki Knidos' ta kazı ve araştırmalar yaparak kent planını ortaya çıkardı. Bu plan o güne değin yapılabilen en ayrıntılı Antik kent planı idi (www.filozof.net/ Er. Tar.: 18/04/2014).

${ }^{10}$ Marafet, Chok Marafet.

${ }^{11}$ Carl von Scherzer (1821 - 1903): Viyana doğumlu Avusturyalı kaşif Karl von Scherzer; 1852 - 1855 yılları arasında Kuzey Amerika, Batı Hindistan ve Orta Amerika'da araştırma gezilerine çıkmış, özellikle Kostarika'da yoğun olarak biyolojik ve ekonomik ilişkiler üzerine incelemelerde bulunmuştur. 1857 - 1859 yılları arasında Avusturya Hükümeti'nin Okyanus'a gönderdiği Novara araştırma gemisinde raportör olarak bulunmuştur. 1869 yllında Avusturya Hükümeti'nin araştırma ekibinde yer almış; Siyam, Çin ve Japonya'daki incelemelere katılmıştır. 1872-1896 yılları arasında İzmir, Leipzig ve Cenova'da başkonsolosluk görevinde bulunmuştur. “İzmir 1873" isimli kitap; aslen Avusturya - Macaristan İmparatorluğu İstanbul Sefareti tarafindan bölgedeki tüm konsolosluklardan istenen, zamanın İzmir başkonsolosu olan Karl Von Scherzer tarafından hazırlanmış bir rapordur (Scherzer, 2001: Numarasız Sayfa) 
milletidir. Ancak çalışkanlık, girişimcilik ve ilerlemecilik gibi özelliklerden yoksundurlar; gamsızlık temel özellikleridir. "Yarın” pek düşünmemektedirler; bu nedenle de en küçük bir sikıntıya düş̧üklerinde hemen borç almakta ve yüksek faiz ödemektedirler; beslenme ihtiyaçların karşılayamayacaklarını hiç düşünmeden tarlalarını kolayca elden çıkarabilmektedirler" (Scherzer, 2001: 26).

\section{3. Şehir}

Türk şehirlerine, şehirleşmesine bakılacak olursa, 19. yüzy1l Türkiye'sinde henüz konuya ilişkin göze çarpan olumlu bir gelişme olmadığı görülür. Sokakların pis ve aşırı dar olmasından ve kentleşme bilincinin henüz hiç oluşmadığından yakınır gezginler çoğu zaman. Bununla birlikte, bölgedeki milliyet çeşitliliği ve Türk insanının yerel görünümü şehre daima canlı bir hava katmıştır. Gezginler şehirlerdeki ağaçlardan kuşlara, çatılardan minarelere kadar pek çok detay üzerinde durarak, okurlarına Batı Anadolu resmi çizmeyi -yanlı veya yansız- başarmıştır.

Yerleşim yerleri özelinde gözlemlerini dile getiren gezginlere değinmeden önce, Türk kasabalarının genel bir resmini çizmiş olan Fellows'a değinmek yerinde olacaktır. Fellows, gördüğü tüm Türk kasabalarını, beyaz minareler hariç, binalar bakımından olduğu kadar; yüksek kayalık dağların eteklerinde konuşlanmış olmaları ve önlerindeki vadinin yine güzel bir manzaraya bağlanması yönüyle konum bakımından da İsviçre köylerine benzetir. Başlıca toprak ürününün pamuk olduğundan ve şimdiye dek Küçük Asya'nın bu bölümündeki gibi geniş, zengin ve ekili alanları başka hiçbir yerde görmediğinden bahseder (Fellows, 1852: 20). Scherzer ise tipik bir Türk mahallesini şöyle tasvir eder: “İnsan bir Türk mahallesini göz önüne getirdiğinde şöyle bir resimle karşılaşacaktır: să̆l sollu yüksek duvarlarla çevrilmiş ve bu duvarların ortasından açılan kapıyla girilen bir ev; hiçbir pencere yoktur ve buna paralel olarak komşuluk ilişkileri düşük düzeydedir; uzun ve eğri büğrü sokaklarda yaşam hareketliliği görülmemektedir" (Scherzer, 2001: 27).

Yerleşim yerleri özeline indiğimizde, Aydın ile ilgili ilk izlenimlerini Chandler ${ }^{12}{ }^{\prime}$ nn paylaştığını söylemek yerinde olacaktır. Gezgin, Aydın ilini "ağaçlı, evleri vasat, yüksek kubbeler ve minarelerin birbirine karıştığı ve arkasında aslen Thorax denilen yüksek bir tepe bulunan büyük ve kalabalık bir şehir" olarak tanımlamaktadır. Chandler; ağaç dallarında, duvarlarda, evlerin çatılarında oturan ve yüksek sesle öten sayısız evcil üveyiğin yanı sıra; yazın ölümcül olabilen sıcağına da değinir (Chandler, 1817: 255).

Gezginlerin hemen hepsinin Batı Anadolu şehirlerine dair izlenimleri ortaktır: dar ve pis sokaklar. Bununla birlikte, yukarıda da görülebileceği üzere, Aydın ilinin -mimari gösterişten uzak olmakla birlikte- ağaçlı ve çatılarını üveyiklerin kapladığı görüntüsünden pek çok gezgin hoşnutlukla bahseder.

\footnotetext{
${ }^{12}$ Richard Chandler (1738 - 1810): İngiltere'de, Elson - Hampshire'da doğdu. 1764 y1lında Dilettanti Cemiyeti tarafından, yanında bir mimar ve bir ressamla birlikte İyonya ve Yunanistan'daki antik şehirleri araştırmak üzere görevlendirildi. Bu gezinin sonucunda iki önemli eser ortaya çıkmıştı: Dilettanti Cemiyeti tarafından basılan, İyonya Antikleri'ne ilişkin iki kitap ve Chandler'ın gezi notlarından oluşan "Travels in Greece, or an Account of a Tour Made at the Expense of the Society Of Dillettanti". Chandler'n diğer eserleri arasında Inscriptiones Antiquae Pleraeque Nondum Editae - Pek Çoğu Yayınlanmamış Antik Yazıtlar (1774), Travels in Asia Minor Küçük Asya'da Seyahat (1775), Travels in Greece - Yunanistan'da Seyahat (1776), History of Ilium - Ilium (Truva) Tarihi - (1803), Life of Bishop Waynflete, Lord High Chancellor to Henry VI - I. Henry'nin Şansölyesi Piskopos Waynflete'nin Hayatı (1811) yer almaktadır. Seyahat yazıları daha sonra, 1825 yılında R. Churton tarafindan the Travels in Asia Minor and Greece (Küçük Asya ve Yunanistan'da Seyahat) adıyla bir araya getirilmiştir. Richard Chandler Türkiye sınırları içerisinde İzmir, Aydın, Kuşadası, Denizli, Çanakkale çevresindeki kasaba ve köylerde ve ağırlıklı olarak buralardaki antik kentlerde bulunmuş, gezi notlarında bu bölgedeki antik şehirlerin yanı sıra burada yaşayan Türk ve azınlıklara ilişkin gözlemlerini de aktarmıştır. Chandler aynı zamanda Alinda antik kentini ziyaret eden ilk Avrupalı olarak bilinmektedir (http://en.wikipedia.org/ Er. Tar.: 18/04/2014).
} 
Walsh da bu şehirde minarelerin, kubbe ve evlerin arasından yükselen selvi, sakız ve çınarla ağaçların ve otların bir orman görüntüsü oluşturduğunu vurgular. Gezgin; şaşırtıcı sayıdaki üveyik ve benzer kuşun bu ağaçların arasını mesken tutarak dalları ve çatıları kaplaması; kesintisiz ve ağlamaklı sesleriyle gün boyunca havayı doldurmaları karşısındaki şaşkınlığını gizlemez (Wilson, 2006:210).

Sonraki yıllarda bölgeye gelen Arundel1 ${ }^{13}$ ise, Aydın'a varış anını ilk gözlemleriyle şöyle paylaşmaktadır: "Hava artık zifiri karanlıktı ve dağlık yolda aşağı yukarı kıvrılarak yolumuza devam etmekteydik ve şayet bir Türk bize doğru yolu göstermeseydi bütün geceyi de böyle sürdürecektik. Güzelhisar'a vardığımızda saat beş - altı arasıydı; şehrin kapıları kapalıydı, fakat bizim geleceğimiz bilindiğinden açılmak üzere beklenmekteydi ve sokaklar arabanın geçemeyeceği kadar darlaşana kadar ilerledik. Çok uzun sürmeyen çabalamamızın ardından evlerle, onların karşılarında uzanan dükkânlar arasında sıkıştık” (Arundell, 1834:218).

Genel Türk kasabası izleniminden ayrı olarak, birkaç yıl arayla iki kez Aydın ilinde de bulunan Fellows, ilk gelişinde kayda değer büyüklükteki modern Aydın'ın evler arasındaki ağaçların çokluğundan dolayı bir köy görünümüne sahip olduğuna değinir (Fellows, 1852:207). 1840'l1 yıllarda gerçekleştirdiği ikinci ziyaretinde ise Fellows, bugünkü Aydın'1 dev bir inşaat alanına benzetir; önceki günlügünde renkliliği ve canlılığıyla kendini cezbeden neredeyse tüm pazarların yeniden yapılmakta ve sokakların hemen hepsinin geçilemez durumda olması Fellows'u hayal kırıklığına uğratmıştır. Bunda mevsim değişikliğinden ötürü sokaklardaki pek çok ağaç yapraklarını dökmüşs olduğundan, şehrin güzelliğinin çoğunu kaybetmiş olduğuna değinir gezgin (Fellows, 1852:242).

Texier ise, Aydın ilinin bölgenin en önemli yerlerinden olduğunu, iç piyasanın ana maddelerinin geçtiği çok büyük bir merkez olduğunu, çarşı ve pazarların geniş ve çok alışverişli olduğunu belirtir. Yine Texier, deprem korkusuyla artık ahşaptan yapılmaya başlanan evlerin bu sefer de - özellikle kavurucu yaz sıcaklarında yangın tehlikesiyle karşı karşıya kaldığından bahsettiği Aydın'da ağaçları aşarak yükselen minareleriyle pek çok cami bulunmakla birlikte, bunlardan mimari veya tarihi önemi olan bir yapıya rastlamadığını ekler; bu sebeple ikametgâh olarak kaba ve kötü yapılmış işlemelerle süslenmiş ahşap konaklardan başka, burada sultanlarla açıktan savaşan değilse bile, sessiz çatışma halinde bulunan Aydın beylerini uzun ömürlü eserler yapmaya yeltenmemekle eleştirir. Texier, şehrin doğu tarafındaki mahallesinin, nehrin kenarında kurulmuş olan tabakhanelerle işgal edilmiş olduğundan, bunların hiçbir sağlık kontrolüne tabi tutulmadığından, tabakhane artıklarının şehrin ortasına bırakıldığından ve pis kokularının da halkın ortasına yayıldığından dem vurur. Ova oldukça iyi ekilmiş durumdadır. Bağlar, zeytinlikler ve incirliklerin ürünleri çok önemli temel ihracatı

\footnotetext{
${ }^{13}$ Francis Vyvyan Jago Arundell (1780 - 1846): İngiliz asıllı antikacı ve seyyah Arundell, İngiltere'de Launceston - Cornwall'da doğmuștur. Memleketi olan Antony'de papaz yardımcılı̆̆ına atanmasını takiben, 1805 yılında Tamar Bölgesi’nde bulunan Landulph'taki papaz evinde görevlendirildi. Yaşamı boyunca antikaya olan ilgisi fazlaydı. 1816'da İzmir'deki bir İngiliz imalathanesine din görevlisi olarak atandı ve burada on dört sene kaldı. İzmir'e yerleştikten kısa süre sonra Küçük Asya'ya bir keşif turu düzenledi. 1826 yılının Mart ve Eylül ayları arasındaki süre boyunca, Asya'nın yedi kilisesine hac ziyareti ve Pisidia'ya keşif gezisinde bulundu ve bunu 1828 yılında kitaplaştırdı. Kitap ilgiyle karşılandı ve bunun verdiği cesaretle 1833 yılında daha önce büyük çoğunluğunu hiçbir Avrupalının görmediği bölgelere 1000 millik bir yolculuğa daha çıktı. Pisidia'daki Antioch'ta özel bir çalışma yaptı ve bu keşifleri içeren iki cilt 1834'te basıldı. Arundell 1835 - 36'da Filistin'e doğru yeni bir tura çıkmışsa da, buna ilişkin notlarını yayımlamadı. İzmir'de yaşarken eski eserler, madeni paralar ve el yazmalarından geniş bir koleksiyon oluşturdu ve İngiltere'ye döndüğünde bu madeni paraları British Museum'a sattı. İzmir ve memleketi Launceston için topladığı materyal hiç kullanılmadı ve muhtemelen kayboldu. 1846 yılında ölen Arundell'in günümüzde üç adet basılı eseri bulunmaktadır: A Visit to the Seven Churches of Asia (Asya'nın Yedi Kilisesi'ne Ziyaret - 1828), Discoveries in Asia Minor: Including a Description of the Ruins of Several Ancient Cities and Especially Antioch of Pisidia (Küçük Asya'da Keşifler: Yedi Antik Kentin ve Özellikle Pisidia Antakya'sı Kalıntılarının Tanıtımı Dahil - 1834), Aimons Notre Prochain (Sonraki Aşkımız - 1854) (http://www.oxforddnb.com/ Er. Tar.: 18/04/2014).
} 
oluşturur. Deri tabaklama zanaatından başka, Aydın'ın pamuk tekstili işi de vardır. Pamuk tekstilinden kastedilen, evler ve odalardaki tezgâhlardır. Çünkü Fransa'daki büyük imalathaneler, doğuda henüz bilinmemektedir (Texier, 2002:114).

Bir diğer gezgin Hamilton Aydın'ın Türklerin yaşadığı bölümünü, içinde -özellikle de şehrin kapısı yakınlarında -pek çok antik parça ve kırık sütun bulunan, büyük bir duvarla çevrili olduğu tasvirini paylaşır. Şehrin biraz dışarısında, paşanın tatarlarından birinin Tire'den dönüşte açık bir alanda karantinada olduğuna şahit olmuştur. Anlaşılan o ki, ülkeyi saran veba salgınından ötürü yolcular şehre girişlerinde gerekli görüldüğünde tecride tabi tutulmaktaydı. Hamilton aynı zamanda bölgenin iyi ekilmiş olduğundan ve burada özellikle fazlaca zeytin, incir ve üzüm bulunduğundan söz etmiştir (Hamilton, 1842:537).

Strickland $^{14}$ ise, tüm Türk kasabalarında olduğu gibi Aydın'da da kirli, dar ve kaldırımları kötü sokaklarına değindiği Aydın ilindeki evlerin genellikle iki kat yüksekliğinde, üst katı da sokağa doğru iki-üç feet çıkıntılı şekilde olduğunu; sokaklarda duvardan başka bir şey görünmemesi amacıyla evlerin, alt katlardaki pencerelerinin genellikle küçük bir avluya bakmakta olduğunu belirtir. Burada tüm dükkânlar Pazar alanında toplandığından, Strickland şehrin geri kalan kısmı sıkıcı ve hayattan uzak olduğunu belirtmektedir (Jardine, 1858:xciv).

\section{4. Çarşılar ve Pazarlar}

Çarşılar ve pazarlar pek çok Avrupalı gezginin ilgisini fazlasıyla çekmiş karakteristik yerlerdir. Pazarlardaki renk cümbüşü, hareketlilik ve insan çeşitliliği, Avrupa kültürüne çok uzak ve bir o kadar da Doğu'ya has oluşumlar olduğundan, çoğu gezgin tarafindan bahse değer bulunmuşlardır.

Fellows, kayda değer büyüklükteki modern Aydın şehrinin, evler arasındaki ağaçların çokluğundan dolayı bir köy görünümüne sahip olduğu izlenimini paylaşır. Alışılageldiği üzere, pazarların ağaçlarla tamamen gölgelendirilmiş sokaklarda kurulu olduğunu ekleyen Fellows; buradaki Pazar yerindeki kıyafetlerin coşkulu çeşitliliği ve genel görüntünün İngiltere'de katıldığı pek çok fuar veya yarıştan, Paris'teki anma günlerinden, Catania ve Napoli'deki karnavallardan katbekat güzel olduğunu belirtir: "Sokaklardaki bitki ve ağaçlar göz alıcı beyaz çarşafların, çeşitli renklerdeki işlemeli şalvarların ve pazardaki fazlaca kadının görüntüsünü olumlu yönde hafifletiyordu; gümüşle işlenmiş açık mavi renk köylü klyafetlerinde sıkça görülmekteydi ve her türban güller ve çeşitli çiçek buketleriyle süslenmişti. Burası, bu tür sahnelerde alışılagelmiş olandan daha gürültülüydü; çünkü kalabalık içinden deve veya yüklü eşekler geçerken, sürücüleri sürekli etraftakileri uyarlyordu. Kadınlar çocuklarını sırtlarına bağlamıştı ve renkli klyafetleri ve madeni paralarla süslenmiş başlıklarıyla çocuklar, ortamın resmedilmeye değer güzelliğine güzellik kattyordu” (Fellows, 1852:207).

\subsection{Seyahat ve Konaklama}

Araştırma kapsamındaki seyahatnamelerin tümünde gezginlerin, kendilerinden sonra Küçük Asya'ya gelecek olan Avrupalı diğer gezgin veya yolculara yol göstermek amacıyla izlenimlerini, yardımcı ve

\footnotetext{
${ }^{14}$ Hugh Edwin Strickland (1811 - 1853): 19. yüzyılın önde gelen doğa bilimcilerindendir, fakat doğa tarihinin pek çok diğer dalında da ismi öne çıkar. 1835 yılında Cracombe'de katıldığı bir sohbette Hamilton'ın Küçük Asya'ya seyahat etmeyi planladığını öğrendi ve geziye kendisi de - klasik önem taşıyan antik kentlere ziyaret ve güney Avrupa jeoloji ve ornitolojisini incelemek üzere davet edildi. Aynı yıl Fransa ve İtalya'nın güneyinden, günümüz Türkiye'sinin batı kıyılarına kadar seyahat etti. Döndükten bir süre sonra, 1853 yılında demiryolu kenarında jeolojik katmanları araştırırken bir tren kazası sonucu 42 yaşındayken hayatını kaybetti (http://www.rhinoresourcecenter.com/ Er. Tar.: 18/04/2014).
} 
rehber niteliğinde bilgilerle eşliğinde sundukları görülmektedir. Söz konusu ipuçları hemen tüm seyahatnamelerin önsözlerinde yer almaktadır.

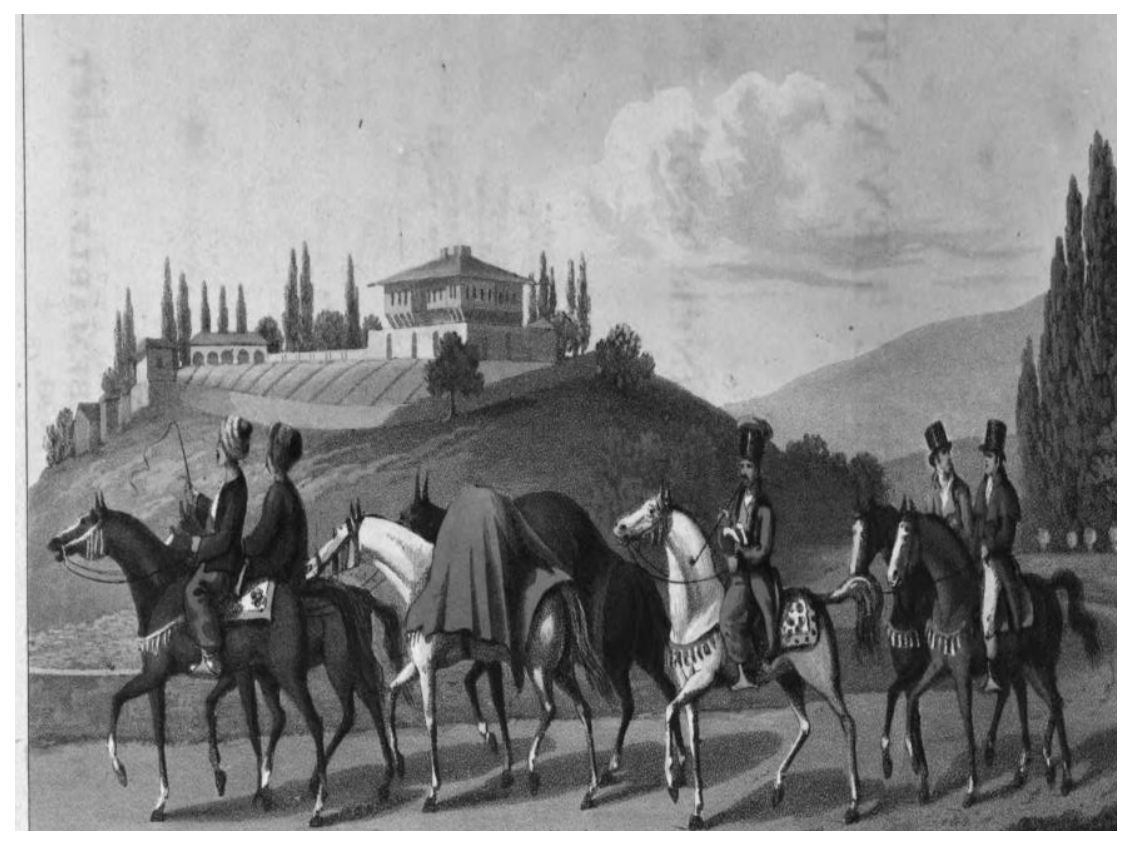

\section{Resim 1 - Türkiye'de Seyahat (Turner, 1820:2)}

Küçük Asya'da seyahat etmek konusundaki izlenimlerini paylaşan ilk gezgin olarak William Martin Leake $^{15}$ 'tir. Leake, kendi gelenek, kültür ve dininden çok farklı öğelere sahip olan Osmanlı topraklarında seyahati anlatırken oldukça keskin bir dil kullanmaktadır: "Modern barbarlık ve dezolasyon arasında Yunan sanat ve uygarlığının izini sürmekten ve bu yolla tarihi bir çırpıda gösterip sanatsal ve coğrafi değeri olan materyaller toplamaktan zevk alan bir gezgin için Küçük Asya kadar verimli bir yer daha yoktur. Maalesef hiçbir Osmanlı toprağının da detayla incelenmesi bu kadar zor değildir. İslam'ın etkileri; uygar Avrupa'ya olan fiziksel yakınlıktan, bilinç zayıflığından ve

\footnotetext{
15 William Martin Leake (1777 - 1860): İngiliz ordu görevlisi, topograf ve antikacı olan Leake, Antik Yunanistan'da yaptığı çalışmaları ve elde ettiği değerli eserler üzerine kazı ve incelemelere daha ilgiyle eğilmeye başladı. 1804 yılında olası bir Fransız saldırısı karşısında Türklere yardım etmek için gönderilen Leake, aynı zamanda Yunanistan coğrafyasını inceleme ve Arnavutluk ve Mora kıyılarını araştırma firsatı buldu. Yunan medeniyetine ait zengin bir madeni para ve antik eser koleksiyonu edinen Leake, 1815 yllında ordudan ayrılmasını müteakip yazdığı çeşitli eserler arasında "Journal of a Tour in Asia Minor, with Comparative Remarks on the Ancient and Modern Geography of that Country" (Küçük Asya Seyahati Günlükleri: Ülkenin Antik ve Modern Coğrafyası Üzerinde Kıyaslamalı Notlarla - 1824), "Travels in the Morea" (Mora'da Yolculuk - 1830) ve Travels in Northern Greece (Kuzey Yunanistan'a Yolculuk - 1835) bulunmaktadır. İkinci eserinde bölgenin arkeolojik zenginliklerini araştırmanın yanı sıra, Türk hâkimiyetinin son dönemlerini yaşayan Yunanistan üzerine derinlemesine inceleme de yapmıştır (http://www.britannica.com/ Er. Tar.: 18/04/2014).
} 
Hıristiyan nüfusun Türklerden çok fazla olmasından ötürü Avrupa Türkiye'sinde daha yumuşak şekilde hayata yansımaktadır: fakat Müslüman ve Hıristiyan dünyasinda değişmekte olan güç dengesinden ötürü bütün Osmanl Imparatorluğu'nu tehdit eden tehlikeye inanmasına rağmen, korktuğu Hıristiyan dünyasından koparılmak Küçük Asya Türk'üne güven vermekte ve ataları bu güzel toprakları işgal edip halefleri de bunca zamandır rahatsız edilmeden istismar edegeldiğinden, Küçük Asya Türk'ü Avrupa Türkiye'sinin işgalcilerin eline öncelikle geçmesi gerektiğini düşünmekte ve dininin emrettiğinin veya doğu insaninin hoşgörüsünün aksine, Hiristiyan kelimesine olan nefretin meşru olduğunu düşünmektedir.

Küçük Asya'da bir gezginin başarısının önündeki engellerin başında ülkenin terk edilmiş hali sayllabilir ki bu en olağan ihtiyaçlara bile erişimi engelleyebilir. Bununla birlikte, güç sahibi kişilerin bitmeyen tartışma ve savaşlarl; İstanbul'daki yönetimin keyfi otoritesi ve sonuçta gezginin başarısının yerel yöneticinin karakterine bağh olmasl; bilimsel seyahat hakkında hiçbir fikri olmayan, ziyaretlerimizin bir düşman işgali hazırlığından veya tarihi kalıntılar arasında hazine aramaktan başka bir amacı olmadığını düşünen Türklerin umursamazlı̆̆ ve şüpheci yaklaşımı... Bu gibi sebeplerle, Küçük Asya gibi bu tür deneyimlerin en yoğun olduğu bölgelere yapılan ziyaretlerin sayısı da oldukça azdır. Şayet gezginin talihi bu gibi olumsuzlukları bertaraf etmeyi veya veba, haydutlar veya yarı barbar toplumdaki herhangi bir başka tehlikeden korunmayı başarırsa bile; bu sefer de iklim, yorgunluk ve mahrumiyet tehditlerinden de kendini korumalıdir.

Küçük Asya'da bir gezginin detaylı inceleme yapabilmesi için hala kllık değiştirmesi, doktor kılığına girmesi gerekmekte ve fazlaca sabır, tüm Avrupa konforlarından feragat, her türlü lüksün saklanması, dil ve insanlara dair bilgi edinilmesi icap etmektedir" (Leake, 1824:iii - vi).

Walsh, Asya Türkiye'sinde seyahat etmeye ve konaklamaya ilişkin bilgi ve gözlemlerini ayrıntılı şekilde dile getirir: "Asya Türkiyesi'nde seyahat etmenin iki şekli vardır. Seyyah sultandan fermanını alıp yanında Tatar bir Yeniçeriyle gideceği yere vardığında bir şehir veya kasabanın paşa yahut müsellimine gelip kendini tanıtır, itimatnamelerini sunar; kendisine bir konak-yanındakilerle birlikte konaklayacağı bir çeşit ev - tahsis edilir ve yerleşmelerine yardımcı olmak için bir çavuş görevlendirilir. Bu ev genellikle bir Rum, Ermeni veya Yahudi'nin ikametgâhıdır. Çavuş sade bir şekilde içeri girer ve yabancı kalmak istediği sürece buradaki her şeyin kullanımına açı olduğunu belirtir. Nazik bir yolcunun hatırına, ev sahiplerinden burada misafir gibi kalmalarını ve en güzel odaların misafire vermelerini isteyebilir. Şayet yolcu konaktaki konfor veya muameleden memnun kalmazsa, başka bir han veya kervansaraya (Tüccar Sarayı) taşınması istenir. Bunların ilki yüksek çatısı ve sade duvarları olan oldukça büyük bir yapıdır ve damlarının büyüklüğüyle zitlık oluşturan atların birer fare gibi kaldı̆̆ Westminster Hall'a benzemektedir. Zemin etrafinca uzanan ve yemlik görevi gören alçak tırabzanlarla duvar arasında pek az mesafe vardır. Buraya bir yolcu geldiğinde herhangi bir soru veya soruşturmada bulunmaksızın atını yeme doğru yöneltir, atın yanına da kendi halısinı sererek yanında yemek için nesi varsa onu yemeye koyulur, zeminde - yemek yediği yerde uyur ve sabah da herhangi bir ödeme yapmaksızın ayrllır. Şehirlerdeki hanlarda yatacak yer biraz daha özenlidir; taşradaki hanlar ise yüksek duvarın yanında güvercin yuvasına benzeyen, merdivenle çıkılan, samanlığa benzer küçük bir odacıktan oluşur. Burada yolcuya kaba ve kirli zemin üzerinde pejmürde bir paspas tahsis edilmiştir; belki de sokakta yiyecek - içecek bulabileceği bir kahvehane de bulunabilir, fakat tüm bunlar nadir rastlanan lükslerdir. Bu çıplak binalar ilk olarak Muhteşem Süleyman'ın veziri Murat Han, sonrasında da sultanların cömertlik ve hayırseverliğinin bir göstergesi olarak, tüm yolculara ücretsiz konaklama sağlamak amacıyla yapılmıştır” (Wilson, 2006:206).

Texier ise bir yabancının Küçük Asya'da seyahat edebilmesi için takip edilmesi gereken bürokrasiye dair tüyolar vermiştir okuruna. "Asya'da dolaşmak isteyen bir gezgin - burada Asya'dan maksat, Izmir'den Basra Körfezi'ne kadar uzanan ve halkın nitelik ve adetleri yaklaşık aynı olan bölgedir - 
bă̆lı bulunduğu elçilik aracılı̆̆ıyla bütün bölgelerde geçerli bir Padişah Fermanı elde etmek zorundadır. Bursa, İzmir vb. illerin valileri, konsolosların isteği üzerine, kendi sınırlar içinde geçerli olan Buyrultuları verirler; fakat bu kâğıtlar, Ferman etkisi taşımaktan çok uzaktır. Kısaca, bir yere gitmek için Tezkire denilen bir kâğıt daha vardır ki, bu ancak posta konak yerlerinden hayvan almaya yarar. Bu son iki tür kâğıdın eksik tarafi, gezgini gümrük kontrolünden muaf tutamamasıdır. Hâlbuki elinde Ferman olan bir kişi, karada veya denizde, hiçbir yerde gümrük vergisi vermez" (Texier, 2002:4-5).

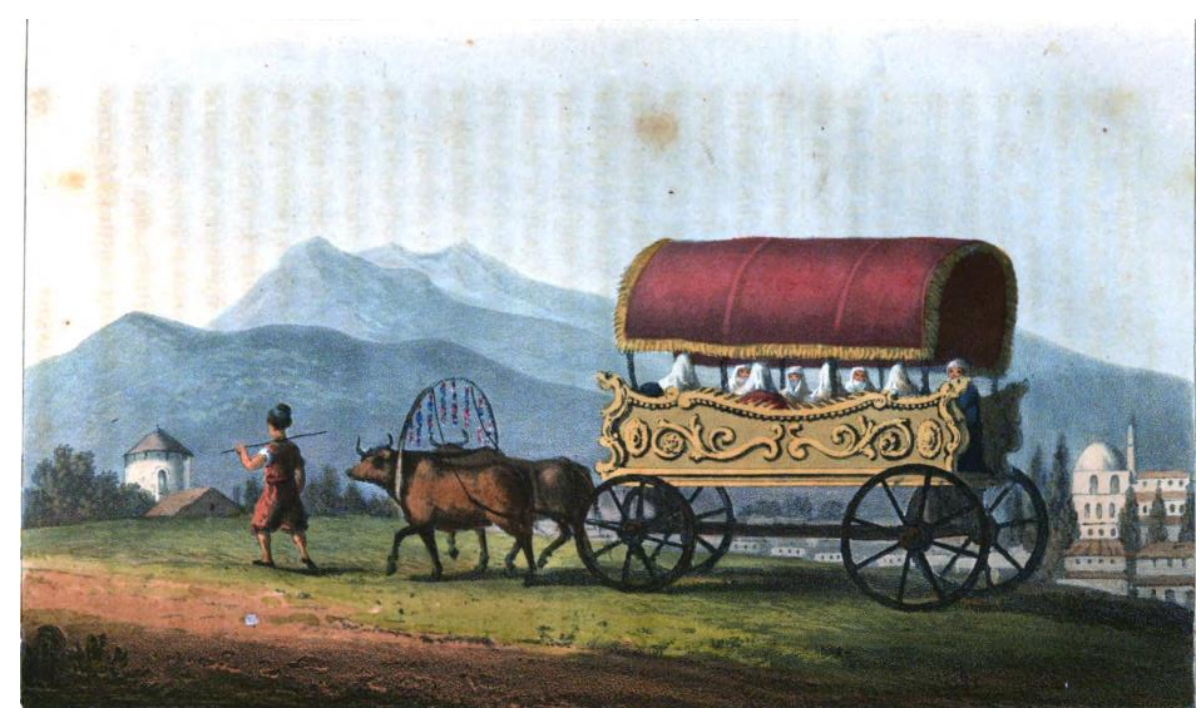

Resim 2 - Seyahat sırasında kullanılan araba (Turner, 1820: 83).

Batı Anadolu'da seyahat sırasında göze çarpan bir diğer husus da, yol üstündeki kahvehanelerin sıklığıdır. Söz konusu kahvehaneler, genellikle kervan yolu üzerinde konumlandırılmış, zeybekler tarafından işletilen, uzun ve yorucu seyahatten bunalmış yolcuların tütün, çay, kahve gibi ihtiyaçlarını temin edebilecekleri yerler olarak inşa edilmiş olmakla birlikte, aynı zamanda yolların ve yolcuların güvenliğini sağlama görevi de verilmiş mekânlardır. Zeybekler bu hizmeti bir miktar haraç karşıllı̆ında yapmakta olduklarından, bazı gezginlerin eleştirilerine de maruz kalmış bulunmaktadırlar. Söz konusu kahvehanelerin sıklığına dikkat çekmek isteyen Arundell, gözlemlerini şu şekilde aktarmaktadır: "Saat dokuza çeyrek kala bir kahvehaneye geldik, buranın yanında bitkin ve yorgun yolculara hayrına su temin etmek amaçlı daire şeklinde bir yapı vardı. Dokuz buçukta veya ona çeyrek kala bir pınarl geçtik ve bir kahvehane ve birkaç evin olduğu bir yere geldik.

Kısa süre sonra sağda yüksek bir dağ geçidinde Nysa harabeleri göründü. Saat onda yine bir kahvehane vardl ve saat on buçukta Kete-kahve denilen bir diğerine geldik. Aslında tütün ve kahve 
gibi keyif malzemeleri bulunmasına rağmen, Karaosmanoğlu tarafindan yolun daha iyi korunması için yapıldığından, buralara muhafiz evleri demek daha doğru olurdu.

Köşk' $e^{16}$ vardlğımızda saat on ikiyi on geçiyordu. Mr. Dethier ve Kyriacos önden gitmişlerdi ve bir siğır sürüsünün geçmesini bekliyorlard. Biri yirmi geçe etrafinda birkaç ev bulunan bir dereyi, ikiye yirmi kala bir çeşmeyi geçtik. İkiyi yirmi geçe bir kahvehaneyi daha geçtik; saat üçe yirmi beş kala iki tane daha kahvehane ve bir çeşme; dörde yirmi kala bir kahvehane daha ve evler gördük. Bunlar dakikası dakikasına yazmamın sebebi, Karaosmanoğlu ailesinin yolcuların güvenlik ve konforuna ne kadar önem verdiklerini göstermektir, çünkü yönetim merkezlerine yaklaştıkça, buradaki kahvehaneler ve çeşmeler bu aile tarafindan yapılmış bulunmaktadır. Toz içinde olmaları haricinde, seyahatimiz boyunca yollar mükemmeldi" (Arundell, 1834:215 - 216). Yol üstü kahvehanelere değinen bir diğer gezgin olan William Turner ${ }^{17}$, söz konusu kulübelerin çoğunun Anadolu'daki yol üzerlerinde bulunmakta olan; bir Türk'ün gün boyunca kalarak gelenlere kahve ikram ettiği, geceleri de burada dört - beş Türk'ün kalarak güvenliği sağladığını belirtmektedir. Turner'ın dediğine göre, eğer bu güvenlik görevlileri olmasaydı yollar tamamen hırsızlarla, genellikle de Levant'taki katillerle dolardı. Gezgin, bu güvenlik görevlisinin hizmeti karşılığında yoldan geçen her Rum'dan sekiz ila on para almakta olduğunu da ekler (Turner, 1820: 64).

Konaklama konusuna gelince, Batı Anadolu'nun bu bakımdan da çok zengin olduğunu söylemek mümkün değildir. Hanların ve kervansarayların bakımsız ve dökük olmaları alışılmış bir durum olarak dile getirilmektedir çoğu zaman.

Chandler bu coğrafyadaki hanların fiziksel yapısına ilişkin genel bilgi sunarak, buraların genellikle ortasında bir çeşme bulunan dikdörtgen veya kare alanlar olduğunu; üst katta açık bir koridor, çeşitli odalar ve dindar Müslümanlar için genellikle bir mescit; alt katta ise yükleriyle birlikte develer, katır veya atlar bulunduğunu belirtir. Chandler'ın gözlemince yolcu bir hana vardığında bir hizmetli boş bir odanın yerini süpürerek, odadaki tek mobilya olan şilteyi yere serer ve yolcuyu yalnız bırakır. "Gün batımıyla kapılar kapanır ve handan ayrılırken hancıya karşı büyük minnettarlık içinde olmanız beklenir" (Chandler, 1817: 83). Walsh ise, tüccarların yerleşerek eşyalarını istiflediği, bazen iki veya üç katı bulan ve birbirlerine geçit veya koridorlarla bağlı odalarla çevrili avlulardan oluşan kervansarayların ortasında genellikle, saf suyun aktığı bir çeşme, etrafında çalılık ve ağaçlar, önünde ise çatılar boyunca yükselen ve hatırı sayılır gölge sağlayan veya dallarından meyve öbeklerinin sarktığı asmalar bulunduğunu ekler. Ona göre bunların bazıları o kadar etkileyici ve mutluluk verici bir görüntüye sahiptir ki yorgun ve bitkin yolcuya en iyi gelebilecek huzuru verir. Ne var ki Walsh, daha önce Müslümanlar tarafından hayırseverliğin kaçınılmaz bir görevi olarak tanımlanıp, sıkı şekilde takip edildikten sonra son zamanlarda zorunluluk olmaktan çıktığı üzere; çeşmeler, hanlar, dindarlık ve hayırseverliğin benzer yapılarının da hızla çürüyüp viran olmaya başladığından ve bunların yerine de yenileri yapılmadığından yakınır (Wilson, 2006:206). Paşanın yerleşim yeri olan Aydın'da bile binaların övünülecek bir yanı olmadığına değinen Walsh, binaların vasat ve pejmürde olduğunu, yolcuların buradaki kervansarayın Türk hanlarından bile daha konforsuz ve virane olduğundan şikâyet tiklerini ekler. "Bunaltıcı derecede sıcak aylarda oldukça tehlikeli bir sıtma baş

\footnotetext{
${ }^{16}$ Arundell burayı Cush ve Cusk olarak yazmaktadır.

${ }^{17}$ William Turner (1792 - 1867): 1792 yılında İngiltere'de doğdu. Babası çok varlıklı bir insan olmasa da, oğluna diplomasi kariyeri sağlayacak bağlantıları olan bir adamdı. 1811 yılında İngiltere Büyükelçiliğinde görevli olarak İstanbul'a geldi. Böylece buradaki, Avrupa tarihinin yatağındaki dünyayı görme firsatı buldu. Bu deneyimlerini daha sonra 1820 'de yayımladığı "a Journal of a Tour of the Levant" eserinde topladı. Bu arada o yıllardaki Batı Gelenekleri uyarınca Türk ve Rumları barbar olarak tanımlıyor ve günlüklerinde bile aşağılayıcı ifadeler kullanıyordu. Özellikle Rum ve Türklerin giyim, batıl inançlar, dil dağılımı ve nüfusuyla ilgilenen Turner, ülkesine döndüğünde bile Homeros zamanından kalan Rum deyimleri üzerine karşılaştırmalı bir çalışma yapmaya devam etti. 1867 yılında hayata veda etti (http://www.forumancientcoins.com/ Er. Tar.: 18/04/2014).
} 
gösteriyor. Salgın bazen o kadar öldürücü olabiliyor ki, yolcu sokaklarda ölü gibi gezerek salgın taşıyan varlıklarla karşılaşmaktansa bu pis, sicaktan kavrulan ve böceklerle dolu evin bir odasına kendini kapatmaya katlanıyor" (Wilson, 2006:210). Yine Walsh'un tanımına göre kervansaray, hanın biraz daha gelişmiş halidir. Asya'nın iç kısımlarıyla ticaretin büyük ölçüde kervanlarla seyahat eden Ermeniler tarafindan yürütülmekte olduğunu belirten Walsh, tüccar grupların bir arada seyahat ettiklerine, katılımcı sayısının yeterince fazla olması halinde ise bu tüccarlardan birinin de kervanı yönettiğine ve düzenlediğine değinir. Bu kervanlara genellikle paralı askerler eşlik eder ve hepsinde bir çeşit silah bulunmaktadır. Paşa veya daha büyük biri sefere çlkacaksa kervan da onu bekler ve bir savaş adamının konvoyundaki tüccarlar filosu gibi onun koruması altında hareket eder. Bu tür bir kervan bazen binlerce kişiden oluşabilir. Normal rotaları boyunca, rutin bir handan daha fazla konaklama imkânı sağlamak amacıyla inşa edilen büyük binalar bulunmaktadır” (Wilson, 2006:206).

Han ve kervansaraylarda konaklamaya ek olarak, gezginlere konaklamaya ilişkin sunulan bir diğer seçenek daha vardır ki bu da gezginin, konaklanacak olan yerleşim yerindeki bir Frenk'in evine misafir edilmesi şeklindedir. Fakat bunun mümkün olabilmesi için, genellikle gezgin için çıkarılmış olan Padişah fermanında yazılması gerekmektedir. Bu Frenk genellikle söz konusu yerleşim yerindeki en muteber veya yaşça en büyük kişidir. Yerleşim yerinin yöneticisi söz konusu ev sahibini görevlendirir. Milas'ta kendisine böyle bir konaklama tahsis edilen Turner, gözlemini şu şekilde aktarır: "Saat beşte şehre vardık ve atlarımızın yüklerini indirdiğimiz geniş ve ferah hanımıza geldik. George ile birlikte Ăga'ya gittik. Ăga'nın sarayı genişti ve Ăga'yı burada çok şılk bir odada bulduk. Ağa beni oldukça medeni bir şekilde karşıladı, bana tütün ve kahve ikram etti ve kendisine konaklama isteyen fermanımı gösterdiğimde beni buradaki Rumların başı olan ak sakallı Proestos'a yönlendirdi.

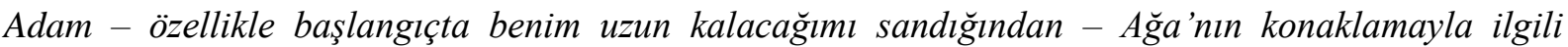
emrinden pek hoşlanmamıştı. Bu fikirle beni önce bitişiğindeki, bir ahıra ait olan yıkık küçük ve pis bir odaya götürdü. Ona burada kalamayacağımı söyledim. Şehirde bir taverna olduğunu duyduğumdan, beni oraya götürürse başına dert açmayacağımı söyledim. Misafirperverlikten ötürü olsa gerek, bu teklifimi kabul etmedi ve Ağa'ya şikâyet etmemden korktuğundan beni kendi evine götürdü ve burada halısı olan oldukça konforlu bir odayı paylaştık” (Turner, 1820: 65).

\subsection{Giyim}

Bölgeye gelen pek çok Avrupalı gezgin, buradaki giyim-kuşamın oryantal dokusundan etkilenmektedir. Özellikle İzmir'deki etnik çeşitlilikten ötürü her halkın kendi geleneksel tarzında giyinmesi bile, sokaktaki veya pazarlardaki renk cümbüşü ve çeşitliliğin dikkat çekici boyutta olmasını kaçınılmaz kılar. Bu çeşitliliğe bir de basma entarilerin çiçekli desenleri eklenince, görüntünün yoruculuğundan da bahseden gezgin sayısı artar.

Önceki yüzyılın sonunda Küçük Asya'da olan Chandler, öncelikle bölgedeki gayrimüslim kadınların giyimini betimler. Bu kadınların, ayak bileklerine kadar uzanan geniş pantolon, kışın genellikle tüy işlenmiş ipek veya kadifeden yapılmış uzun ve zengin bir yelek giydiklerinden; bellerine ise altın veya gümüş tokalı, işli kemer taktıklarından söz eder. Kadınların saçları örülüdür ve genellikle gür bir şekilde sırtlarından dökülür. Bazı kızların saçında yirmi kalın örgü tutamı ve ayrıca başı bir taç gibi çevreleyen; çiçeklerle, tüylerle, inci veya mücevheratla süslenmiş örgüler bulunduğuna değinen Chandler, kıyafetlerin ve çantaların da oldukça farklı olduğundan, pantolonların Sappho ${ }^{18}$, nun bir parçasında belirtilene olan benzerliğinden ve birbirlerini ziyarete gittiklerinde başlarının üzerine kenarları altın dokulu şeffaf bir tülbent taktıklarından da söz eder (Chandler, 1817: 82).

\footnotetext{
${ }^{18}$ Sappho: M.Ö. 615 yılında Lesbos (Midilli) Adası'nda doğmuş kadın şair ve -söylenceye göre- Yunan Tiyatrosu'nun ilk kadın oyun yazarıdır. Lezbiyenliğin doğduğu ve adını da buradan aldığı düşünülen Lesbos Adası sakini olan Sappho'nun lezbiyen olduğu ve şiirlerini âşık olduğu bir kadına yazdığı bilinmektedir.
} 


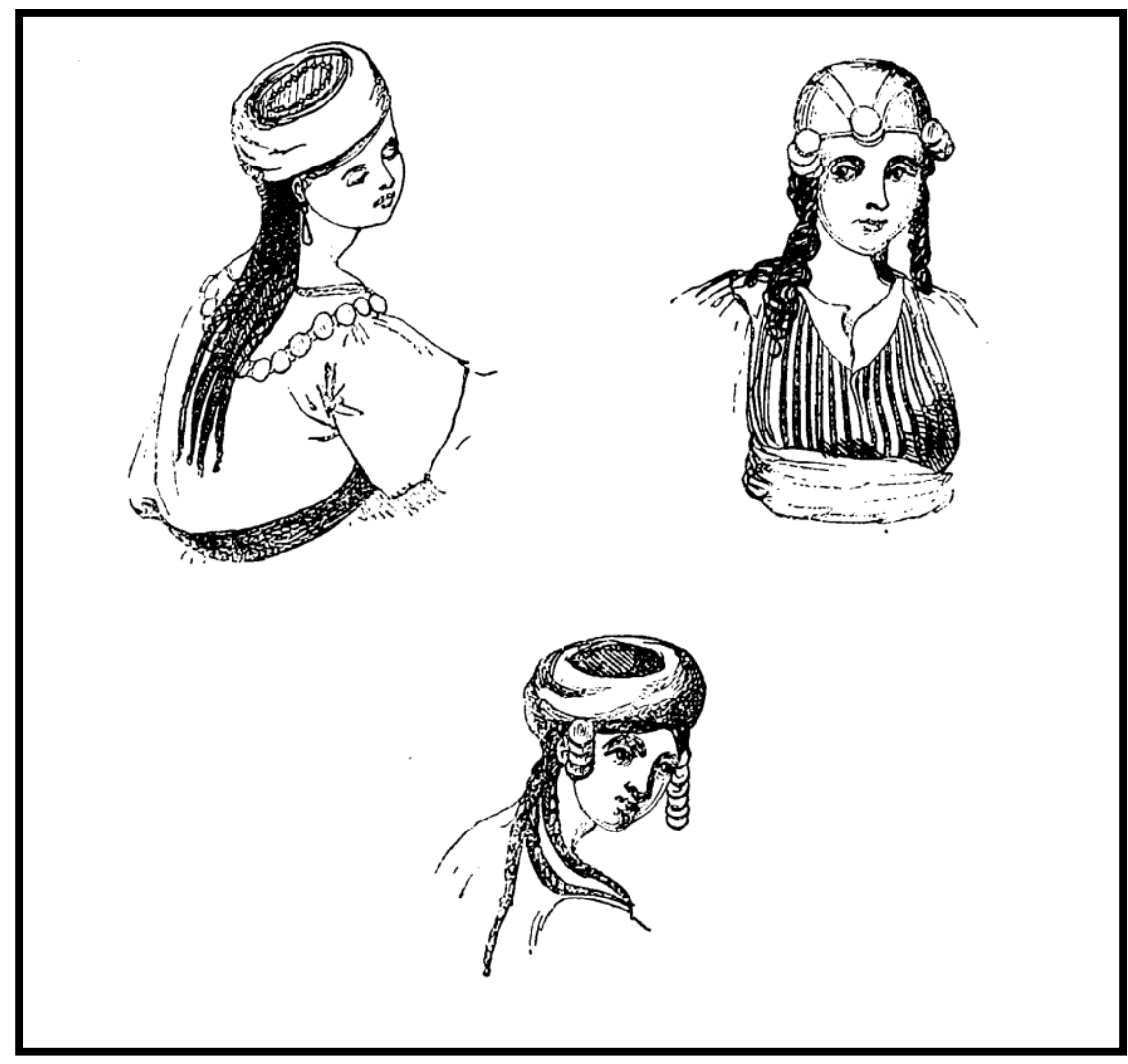

Resim 3 - Frenk kadınının saçlarından örnekler (Fellows, 1852:326).

İstanbul'da beyaz olan yüz örtülerinin burada siyaha dönmesi dikkat çekicidir. Knight ${ }^{19}$, Batı Anadolu'daki giyim tarzının İstanbul'dakine nazaran çok daha oryantal bir görünümü olduğuna, Frenk giysilerinin bile çeşitliliğinin Anadolu'nun bu bölümünde arttığına değinir: Başkentteki yüz örtüleri istisnasız beyaz olmasına rağmen, Asya'nın bu bölümündeki kadınlar - bir tür soytarı maskesine benzeyen siyah yüz örtüsü takıyorlar. İzmir halkının klyafetleri İstanbul'dakilerden bariz şekilde daha oryantal. Buradaki Frenk'lerin kuyafetleri bile diğerlerinden daha çeşitli. Ermenilerin kabarı kalpakları, soluk benizli Farsların koyun derisinden yapılma sivri siyah şapkaları, eski Osmanlıların zengin sarıkları, modern Müslüman modasının isteksiz takipçilerinin fesleri, dervişlerin şeker kalıbı şeklindeki sarıkları bir o kadar yüksek olan Zeybek şapkaları, Rum papazların daha alçak sipersiz şapkaları, Amerikan kaptanların geniş siperli hasır şapkaları, Ingiliz denizcilerin daha avare şapkaları, deniz subaylarının kalkık kenarlı şapkaları, keşişlerin tıraşlı taçları, Yahudilerin alınlarına bağladıkları mendil, Rum ve Italyanların çeşitli başlıklarının yanında çirkin Avrupalı şapkalarının çoğunu tarif etmek için kalemden çok firça gerekir: sadece bunlar bile seyyahın gözünde öyle bir istek oluşturur ki, böylesine çekici bir sahnenin muhakemesini yapmak için sürekli tetikte olması gerekir (Knight, 1839:292 - 293).

İzmir'e varışının ertesi günü, farklı düzen ve mezheplerden olan Türklerin giyimlerindeki çeşitlilik Fellows'un da ilgisini çeker. Fellows, Avrupalıların giyim tarzından çok uzak olan bu giyim ve başa takılan objeleri anlatmanın imkânsız olduğundan bahseder. Kadınların uzaktan hoş görünen, fakat

\footnotetext{
${ }^{19}$ William Knight: İngiliz gezgin William Knight, 1839 yılında yayımlanan "Oriental Outlines or a Rambler's Recollections of a Tour in Turkey, Greece \& Tuscany" (Türkiye, Yunanistan ve Toskana'ya Yolculuğa Dair Oryantal Notlar veya bir Gezginin Anıları) isimli seyahatnameyi kaleme almıştır.
} 
yaklaştıkça tek gözleri hariç her yerlerini örttüğü görülen beyaz çarşafları ve yüzlerini de kapatan at kılından maskeleri veya örtüleri dikkat çekicidir. Bununla birlikte Fellows kıyafetlerdeki muazzam işlemelere ve Türklerin bu kıyafetlere akıl almaz paralar verdiklerini; çocukların giysilerinde bile bulunan altın işlemeler abartılı olduğuna değinir (Fellows, 1852:2). Baharın gelmesiyle kadınların başlıklarına da zevkle dağ laleleri, fulya ve süsen çiçekleriyle işlenir, bu durum genel renk cümbüşüne çeşitlilik ve eğlence katar. Bu baş aksesuarlarını süsleme işi sadece Türk halkına özgü değildir. Fellows, Rum kadınların da saçlarını ve türbanlarını daha şatafatlı şekilde yaptıklarından; çiçekler, kurdeleler, tülbentlerle süsleyip genellikle tepesine altın süslemeli bir takke koyduklarından; çocukların saçlarına takılan altın veya gümüş paralarla bazılarının sırtından tıpkı Mısırlılarda olduğu gibi 20 - 30 ince tutam sarktığından bahseder (Fellows, 1852:9). Fellows, genellikle Rum tarzında giyinmiş kadınların fazlaca pahalı mücevherat veya işlemeye boğulmamış kıyafetlerinin şıklığı ve görkeminin genel ortamda olumlu bir etki yarattığını; kıyafetleri giyenlerinse ayrıca hoş olduğunu belirtir. Bir sonraki bölümde değinileceği üzere, Fellows'un deyimiyle "Frenk nüfusu içinde her ortamdaki özenli giyimleri, İzmir kadınlarının belirgin bir özelliğiydi. Bu, sokaklardan geçen herkesin gözlemleyebileceği bir şeydi: günün her saatinde pencerede veya kapı önünde çiçeklerle ve mücevherlerle süslenmiş, baş aksesuarı dört dörtlük bir kadın görmek mümkündür" (Fellows, 1852:235). Fellows, aynı zamanda Nazilli’de gördüğü genç askerlerin giysilerine ilişkin tasvirlerini fikirleriyle süsleyerek sunar okuyucuya: "Kasabada dolanan pek çok genç asker gözlemledim: çeşitli renklerde fakat genellikle gri renkte, çocukların giydiği klsa ceket giymekteydiler; içlik veya gömlekleri yoktu ve feslerinin beyaz astarı kulaklarının üzerine kadar çekilmişti; modern Türk'ün kendine özgü gururu olan pantolonlart genellikle beyaz ve o kadar boldu ki, uçkur etrafindan sarkiyordu; sart ve genellikle kirli olan botların ise topuklarına basılmıs, bizim Wellington botlarımız gibi eskitilmeye çalışılmıştı; fakat Türkler pantolonlarının geniş paçalarını bu botların içine sokuyorlar ve alışılageldiği üzere derbeder ş̧ekilde yürüyorlardı. Bacakları dizlerinden dışarı doğru bükülmeye Türk şeklinde oturmaktan ötürü epeydir alışıktı ve bu duruş emir verirken onları daha da güçlendiriyordu” (Fellows, 1852:246).

Buradaki en çarpıcı şeyin özellikle farklı Türk sınıflarına ve burada bir araya gelen heterojen milletlere ait alışılmadık ve iç açıcı kostümler olduğuna değinen Hamilton ise bölge insanının giyimine dair şu görüşlerini paylaşır: Dükkânının önünde çömelmiş, geniş elbisesinin içindeki ağır ve ciddi tacir veya tezgâhtar; bir insanın kaldıramayacağı gibi görünen yükünün altında iki büklüm olmuş güçlü, aktif ve neredeyse devasa hamalla tezat oluşturur... çılak bacaklarl, beyaz pantolonları veya kirli fesleri etrafinda doladıkları pamuk bez parçası ile tüccar klyafeti ne kadar gösterişliyse, bu hamallarınki de o derece basit. Yine, çılak bacaklarl, uyluklarına oturan fakat arkada bollaşan beyaz pantolonlartyla, dağlarda ve Menderes kıylarında yaşayan, demir mihlı botlarlyla vakur yürüyen veya satmak için kömür yükledikleri eşek veya develerini süren zeybeklerin püsküllü ve saçakl, yüksek ve gösterişli sarıkları buradaki soluk kahverengi giyinmiş Yörük veya Türklerinkinden çok farkl. Sonra büyük kalpakları, dökümlü giysileri ve tıraşlı çeneleriyle Ermeniler ve Levantenler; açık alınları, uzun keçi sakalları ve oldukça açık boyunlarıyla huysuz görünüşlü ve açık renk saçlı Yahudiler" (Hamilton, 1842: 58).

\subsection{Kadın}

Dönem Türk toplumunda kadının -özellikle erkeklerin bulunduğu- sosyal hayattan mümkün olduğunca tecrit edilmiş olarak yaşadığını görüyoruz. Pek çok Batılı gezgin Osmanlı'daki bu genel durumdan iğneleyici ve eleştirel bir üslupla bahsetmektedir. Ne var ki, Osmanlı'nın kalan kısmından farklı olarak, Batı Anadolu ve özellikle İzmir'de yaşayan Rum kadınlarının güzelliği ve bu topraklarda az rastlanır cüretkârlığı Avrupalı misafirlerimizi cezbetmektedir. 
Chandler Osmanlı toplumunda Türk kadınlarının ve diğer bazı milletlerden olan kadınların özenle gizli tutulduklarını ifade ederek söze başlar. Erkek egemen toplumda kadının bir mahremiyet öğesiymişçesine gizlenmesi, yüzünün tülle kapalıyken bile görülmesinin önlenmesi olağan ve gerekli bir husustur. Kadın, dışarı çıktığında beyaz satene sarınarak bot giyer, yüzünü örter. Teninin görünmesi mümkün olmamakla birlikte, vücut hatlarının belli olması dahi özenle önlenir (Chandler, 1817: 82).

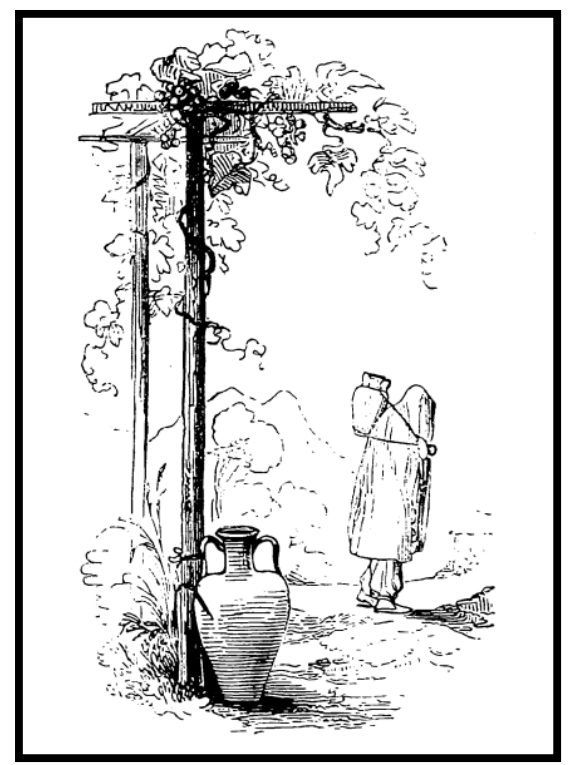

Resim 4 - Milas yakınlarında su taşıyan bir Türk kadını (Fellows, 1852:193).

Keppel ise bu coğrafyada kadınların söylediği kadar kendilerini sakınmadıklarını dile getirmektedir. Türkiye'deki gezginlerin, kadınların özellikle Hıristiyan erkeklere örtüsüz yakalanma korkusundan bahsetmesi bir moda haline gelmiş durumda olduğundan bahseden gezgin, aksi yöndeki şahsi gözlemini ekler: "Uygun bir firsatı olan hiçbir Türk kadınının, şayet yüzü görülmeye değerse, yüz örtüsünü açmaya karşı koymayacağını düşünüyorum” (Keppel, 1831:250). 


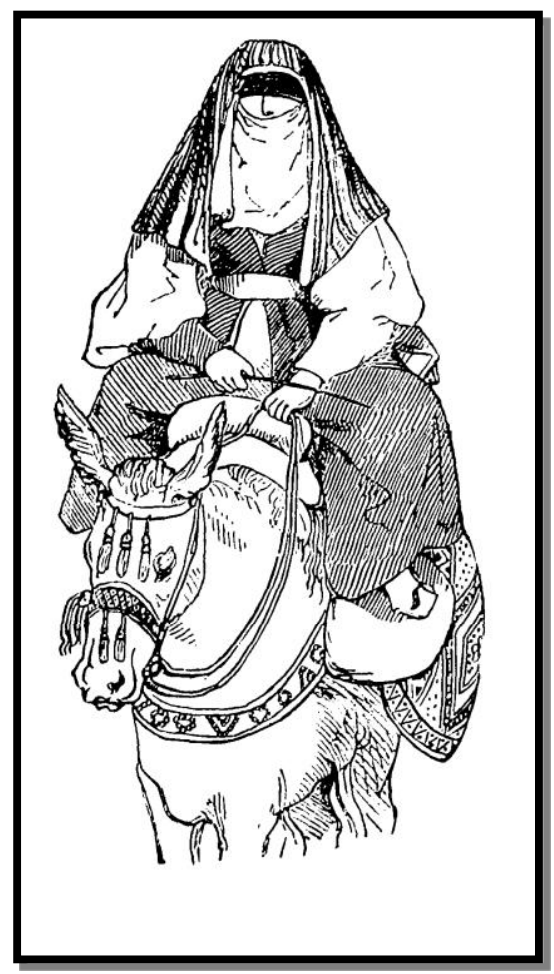

Resim 5 - Aydın yakınlarında bir Türk kadını (Fellows, 1852:240)

Strickland ise bu coğrafyada karşılaştığı kadınlar konusunda bu kadar şanslı değildir. Kadınların erkeklere, özellikle yabancılara karşı aşırı muhafazakâr davrandığını belirten Strickland, Batı Anadolu sokaklarında az sayıda görülen kadınların, yüz kısımlarını da siyah bir örtüyle kapattıklarından, baştan aşağı beyaz bir çarşafla örtünerek; yoldan bir erkek geçmesi halinde sırtlarını kibarca döndüklerinden söz eder (Jardine, 1858:xciv). Türk kadınının toplumdaki yeri, bunun sebepleri ve sonuçlarına dair en detaylı analizi ise Scherzer sunar: "Türk insanının milletlere karşı kendilerini tecrit ederek yaşamalarının temel nedenlerinden bir tanesi, inançlarına bağll olarak, kadınların geri planda olmasıdır. Türkler arasında kadın, aracılık görevi üstlenen, dengeleyen, teşvik eden ve katılan unsur olmaktan çok, genellikle bunun tam aksidir. Genel görüş olan kadının erkeğe tabi olduğu görüşü, buna bağll olarak diğer erkeklerle konuşturulmaması ve onlardan gizlenmesi, toplumda birçok olumsuzluklara yol açmakta ve toplumsal yaşamı etkilemektedir. Öncelikle, kadınların bulunduğu avlu, bahçe ve hareme bir yabancının girmesi kesinlikle yasaktır. Özellikle evlerin dıs duvarları yüksek yapılarak, bir evden diğer evin görülmesi engellenmeye çalışılmaktadır... Bu kötü gelenek sonucu, kadın ev işleri dışında kocasına yardımcı olamamakta; işe yaramaz ve can sıkıcı bir halde evde yaşamını sürdürmektedir. Kadının toplumsal yaşamda bu kadar geri planda kalması, onun inanç konusunda çoğunlukla fanatik olmasına ve zihinsel gelişimini sağlayamadığ için de çocuklarına iyi bir eğitim verememesine yol açmaktadır. Kadının bu konumu, tüm bir sistem üzerine fikir sahibi olmak için yeterlidir" (Scherzer, 2001: 27).

Araştırmamız kapsamında, 19. yüzyılda Batı Anadolu'ya en son gelen Barth ${ }^{20}{ }_{1 n}$ gözlemi ise Avrupa kültürünün tartışmasız hareme kadar girdiği ve burada bir şeyleri değiştirdiği yönündedir; fakat bunun

${ }^{20}$ Hans Barth (1862-1928): Uzun yıllar Roma'da yaşamış ve “Berliner Tageblatt" adlı Alman gazetesinin muhabirliğini yapmıştır. Yaşadığı dönemi iyi gözlemlemeye çalışmış bir gazetecidir. Bu özellikleri; 1897 yılında yayımlanan "Türke, Wehre Dich!” (Türk, Savun Kendini!) adlı kitabında belgelere dayanan çalışması ve o dönemde Osmanlı üzerindeki Avrupa'nın çıkar hesaplarını gözler önüne sermeye çalıştığı emek-yoğun üründen 
sonuçlarının ne olacağı konusunda bir hüküm vermekten kaçınır Barth. Yazara göre; 'artık bir Türk kadınının yanına çarpık bacaklı oğlunu veya kırmızı güllü şalvarlı kızını alarak aşağılık gâvurların Frenk sokağına alışverişe veya Marina'ya gezmeye gitmesi hiç de olağanüstü bir şey değildir'. Türk iskarpinlerinin Viyana çizmeleriyle yer değiştirmesi gibi, romantik şalvarların da yerini Avrupa kökenli elbiselere bıraktığını dile getiren gezgin; çarşafların da, özellikle güzel olan kadınlarda oldukça inceldiğinden dem vurmaktadır. Öyle ki, neredeyse odalıkların o gizemli güzelliğini Avrupa'nın sıradan güzelliğine indirgeme tehlikesiyle karşı karşıya getirmiştir. Türk kadınının gezintileri henüz, kapalı arabaların pencerelerinden beğenilen bir gâvur erkeğine yarı açık yüzden gülümsemeyle gerçekleşmekte ve bir zamanların ahlak bekçisi haremağası, bir süse veya bir uşağa indirgenmektedir. Bu güneyli esmer güzeller arasında beyaz tenli, sarışın Cermen kızı da görmek de mümkün olmaktadır (Pınar, 2001:100).

\subsection{Müzik-Dans}

Bölgeye gelen seyyahlar bölgenin yalnızca coğrafi yapısı ve tarihi hakkında değil, kültürün önemli bir bölümünü oluşturan bölgeye has müzik ve danslar hakkında da seyahatnamelerinde az da olsa bilgi sunmuştur. Bu konular hakkında bilgi veren başlıca seyyahlar Fellows ve Hamilton'dır.

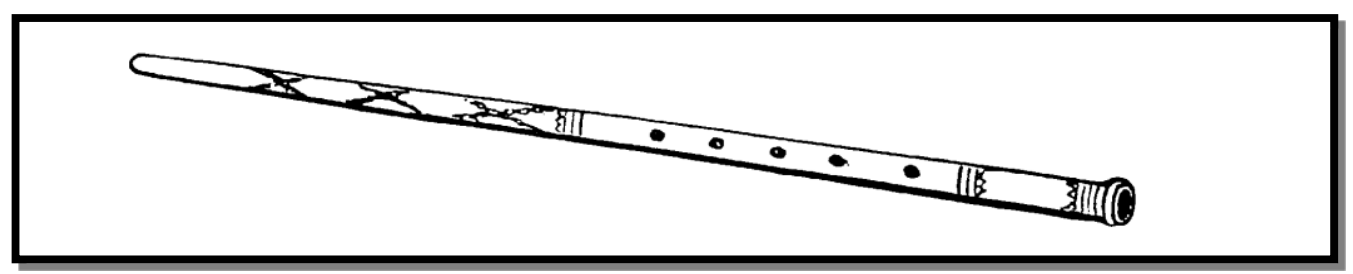

Resim 6 -Fellows'un çizimiyle kaval (Fellows, 1852:49).

Fellows, bu bölgede yaygın olarak kullanılan, keçi çobanlarından edindiği, kaval ve saz adı verilen iki müzik aletinden bahseder. Bunlara flüt ve bir çeşit gitar diyen gezgin, çobanlar tarafından yapılmış aletler olduğunu da ekler. Pek çok havada müzik çalmanın mümkün olduğu bu aletleri dinleyen gezgin, İstanbul'da izleme firsatı bulduğu Dans Eden Dervişleri izlerken çalan bir şarkıyı burada çalınca tanır.

anlıyoruz. Barth’ın bir diğer kitabı da, metinlerinden anladığımız kadarıyla sık sık geldiği Anadolu ve özellikle İzmir üzerinedir. Gözlemciliği kadar kalemi de güçlü olan yazar, yaşadığı dönemde gelişen politik olayları yakından incelediği gibi, bunun sonuçları olan toplumsal olayları da mercek altına yatırabilmiş ve kendi yorumu doğrultusunda dünyanın almakta olduğu hali alaylı bir dilde kaleme almıştır. Barth, 1893 yılında kaleme aldığı "Unter Südlichem Himmel” (Güney Göğü Altında adlı kitabında İtalya ve Türkiye üzerine yazmıştır. Türkiye bölümüyse dört yazıdan oluşan İzmir üzerinedir: İzmirli Kadınlar, İzmir, Küçük Asya'da Bir Köy: Cumaovası, Doğu'da Bira Üzerine İncelemeler (Pınar, 1996:93). 


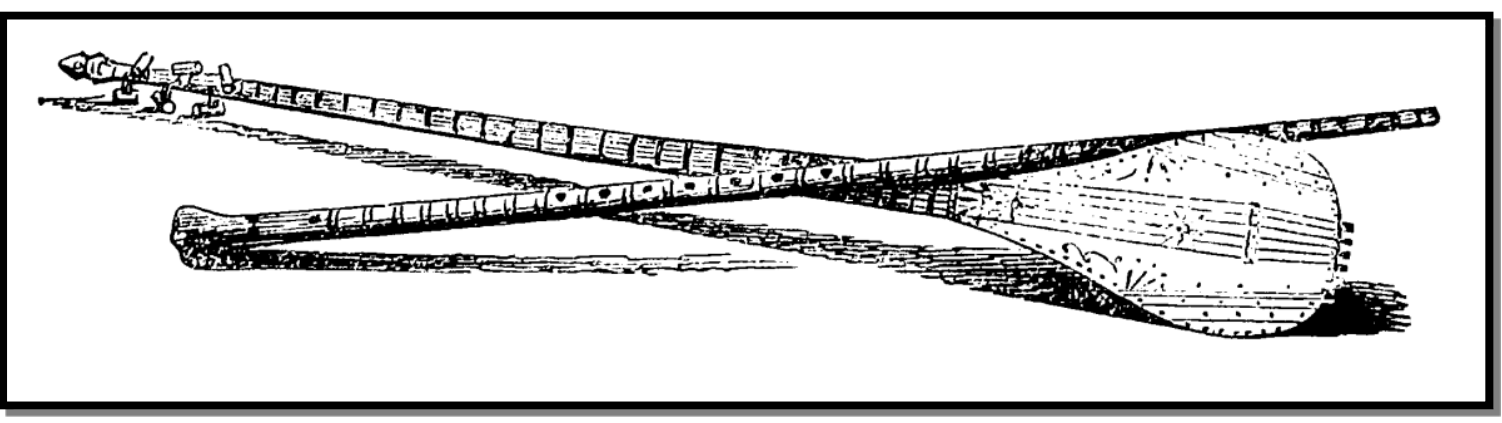

Resim 7 - Fellows'un çizimiyle kaval ve saz (Fellows, 1852: 188)

Bununla birlikte Fellows, bu müzik aletlerinin çalma şekli ve hatta çalarken takınılan tavrın bile British Museum'da sergilenen bir Misır papirüsündekinin aynı olduğunu vurgular (Fellows, 1852:188).

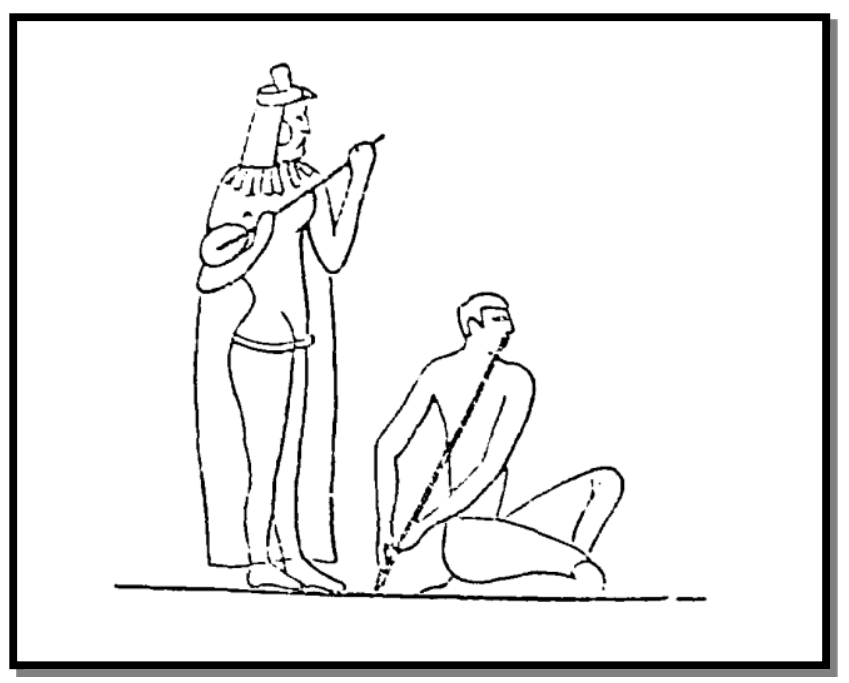

Resim 8 - British Museum'daki Mısır papirüsündeki çalgılar (Fellows, 1852:189).

Yörüklerin ve Rumların geleneksel danslarını izleme firsatı bulmuş Fellows, yerel halkın zeybek dansının ağırlığı ve dans edenlerin senkronu konusundaki hayranlığını dile getirmeden edememiştir: "Çok geçmeden, bu ülkede her evde bulunan bir ud veya gitarm" ${ }^{21}$ sesi duyuldu ve ev sahiplerimizden bir delikanlı; hepsi benzersiz, fakat basit, vahşi ve oldukça ahenkli pek çok ezgi çaldl. Bir dansı olduğu söylenen ve hayran kaldığımız ă̆ır bir melodi çalmaya başladı; daire genişletildi ve kavasımız ortaya geçerek Yörük veya çobanlara ait olduğunu söylediği benzersiz bir dansa başladl; bu dans oldukça yavaştl, figürler iyi çalışılmıştı ve dans ederken yüz ekşitiliyordu. Kavasın ardından bir Rum devam etti ve antik eserlerdeki faun ve ayinlerdeki figürlerin bu kadar doğru sunulması karşısında hayran kaldık. Bay Scharf daha önce bunların - benim bilmediŭim - bazı çizimlerini yapmışı; kolların yukarı kaldırılarak kıvrılması, başın yana eğilmesi, topuğun kaldırılması, kasların görünmesi - ki herkesin bacak ve ayakları çıplaktı - bir antik Yunan kabartmasındakine tıpatıp benziyordu. Kastanyet benzeri parmak şılklatmalar ise saza mükemmel zamanlamayla eşlik ediyordu. Bu, modern kuzey danslarındaki gibi bir egzersiz veya spor dansı değil, yavaş hareketlerde oluşan bir solo dans.

${ }^{21} \mathrm{Saz}$ 
Ve görünüşe göre Taglioni'nin ${ }^{22}$ performansından bile daha çok çalışılmış: peki bu çadırlı köylüler bu hareketleri nerede öğrenmişti? Bu tür başarılar için okullarl, operalarl, herhangi bir teatral temsilleri yok; fakat deyim yerindeyse bu gelenek dügünlerde ve şenliklerde insanları güldürmek için dans eden erkek çocuklarından geçmiş" (Fellows, 1852:289).

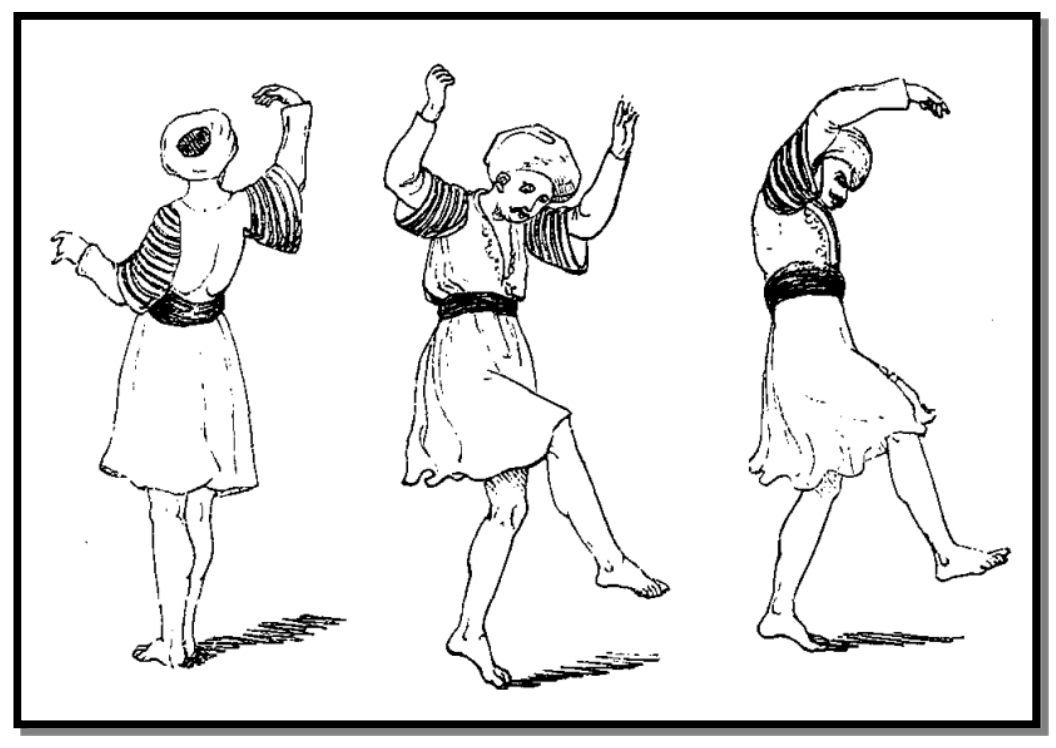

Resim 9 - Yörük dansı (Fellows, 1852:290).

Hamilton da Aydın Yöresinin geleneksel halk dansını izleme firsatı bulmuştur ve gözlemlerini şöyle aktarır: "Akşam Tatar'ın ricası üzerine, burada oldukça meşhur olan dansçı çocukları çağırttım. Aslen Aydın - Güzelhisar'da 23 gelmekte ve yetişkin erkek görünümüne sahip olduklarından, kendilerine çok da uygun olmayan "Küçük" ismiyle anılmaktaydılar. Danslarl pek zarif değildi, fakat yaşlı Türkler performanstan oldukça memnun görünmekteydiler. Genel olarak vücudun kabaca bükülmesinden oluşuyordu ve en azından oldukça zor görünmekteydi; uzun kostümleri ve tunikleri ise onları büyük ölçüde efemine göstermekteydi" (Hamilton, 1842:525).

\subsection{Yönetim}

Aydın ili ve dolaylarında 18. yüzyılın ikinci yarısından 19. yüzyılın ilk on beş yılına kadar hüküm süren Karaosmanoğulları ailesinin, yörenin özellikle tarımda gelişmesine önemli katkılarda bulundukları, bu amaçla Rum nüfusun buralara yerleşmesini özendirdikleri anlaşılmaktadır. $\mathrm{Bu}$ dönemde bazı ailelerin Mora Arkadiası'ndan bile göç ettikleri kimi tarihçilerce belirtilmektedir. İkinci Mahmud'un ayanları etkisizleştirme çabalarından sonra bu ailenin de etkisi azalmıştır. Ancak ailenin kurduğu düzenin, sert tutumlarına karşın bir ölçüde benimsendiği anlaşılmaktadır. Daha sonra bu ayanlar eski güçlerine kavuşabilmek için çaba göstermişlerdir. 1829'da Zeybeklerin isyanından sonra Hasan Paşa'ya karşı pek direniş göstermeyen ayanlar, onun ölümünden ve mütesellimliklerin kendilerine ihale edilmesinden sonra, bu isyanı bastırmışlardır (Yurt Ansiklopedisi, C. 2, s. 990).

\footnotetext{
${ }^{22}$ Marie Taglioni (d. 23 Nisan 1804, İsveç - ö. 24 Nisan 1884, Fransa) ünlü İtalyan balerin, 19. yüzyıl romantik balesinde çağ açmış, Avrupa dans tarihinin önemli figürlerinden biri.

${ }^{23}$ Aidin - Ghieuzel Hissar
} 
Karaosmaoğulları ailesi, yönetimde oldukları süre boyunca, tebaaları tarafından çok sevilen bir aileydi. Seyahatnamesinde binlerce Mora yerlisi Karaosmanoğlu'nun 1 lımlı yönetimi altında yerleştiğine, fakat bundan da büyük sayıda bir kesim Rum İsyanı'ndan sonra buraya kaçtığına değinen Keppel, İzmir ve çevresi de neredeyse tamamen karşı kıyıdan gelen Rumlarla dolduğunu belirtir. Bu, Karaosmanoğlu ailesinin saygınlığının bir işaretidir (Keppel, 1831:323). Karaosmanoğulları'na ve ayanlık yönetimine ilişkin çarpıcı bilgi ve gözlemler sunmaktadır: "Modern Manisa pek çok gezgin tarafindan ziyaret edilmiş. Şu anki yoksullaşmış ve neredeyse terk edilmiş durumu, Karaosmanoğlu ailesinin başkentiykenki bol mahsullü ve kalabalık nüfuslu haliyle tezat oluşturmakta. Tüm Türk sınıflarına karşı siyasi eşitlik sağlamak ve miras geleneğini bile ortadan kaldırmak amaçlı Türk politikası prensibinden daha önce bahsettim: hiçbir oğul babasını malvarlı̆̆ını ve hatta aile ismini miras alamıyor. Kalıtsal intikale karşı olan bu genel kaidenin istisnaları arasında, başları Manisa'da yaşayan, Aeolis, Ioania ve Lydia'nın büyük bölümünü içine alan - Menderes'ten Propontis'e kadar olan zengin bir alana hükmeden Karaosmanoğlu Ailesi vardı. Bu aile hepsi ayn soydan gelen; ilgi, görenek ve bağlllık bakımından derebeye - ailenin reisine bağll birçok beyden oluşmaktaydl. Bu ataerkil yönetim şeklinin alışllagelmiş olana - yetkiyi geçici bir yöneticiye, yani paşaya vermeye nazaran avantajları birkaç kelimeyle şöyle gösterilebilir. Paşa, yönettiği bölgenin gelirlerini açık artırmayla satın alır ve aslında koruyucusu olması gerektiği çiftçilere zulmetmekle daha çok ilgilenir. Başkentteki yöneticilerden ve kendi mahkemesinin hükümlerinden dolayl, uzlaşmanın tek yolu olan rüşvete başvurmak zorunda kalır. Her tür istismardan kâr çıkaran paşa, bunların başlıca destekleyicisidir. Saylsız vergiden ötürü, yönettiği kişiler tarafindan nefret edilir ve bu sebeple kendini korumaları için hak ettiği üzere paralı yabancılardan oluşan bir çete tutar. İstikrarsız yönetimini ne zaman bırakmak zorunda kalacağı belli olmadığından, mümkün olan en kısa zamanda zengin olmaya bakar. Bu berbat yönetim sisteminin giderleri toprak mahsullerinden karşılanmalıdır.

Diğer tarafta derebeyi, yani yönetimi miras alan yönetici, mülkünü çocuklarına bırakma ümidiyle, bu ülkenin zenginlikleri konusunda yönettiği insanlarla aynı doğrultuda düşünür. Derebeyin, işbirliği için evindeki pek çok diğer beyden ve onların da kendi bağlı kişilerine tabi olması bir uzlaşma ruhunun oluşumunu ve sonuçta da her sınıfin zenginliğini sağlar. Bu sözlerimin teorik birer çıkarım olmadı̆̆ını göstermek için, Manisa'nın eskiden derebeyi tarafindan yönetilen ve şimdiki virane hallerini karşılaştıralım. Karaosmanoğlu ailesinin yönetimi süresince mülke sayg gösterilirdi, adalet eşit şekilde sağlanırdl, tarım teşvik edilir ve ticaretin korunması sağlanırdl. Despotluğun bu şekilde azaltılması, yakın zamanda baskıcı yöneticilerinin teröründen buraya sığındı̆̆ı için mutlu olan pek çok insanı çekti. Peloponessus'tan, geçici toprak ăgalarının vergi ve haraçlarından kaçan pek çok Rum Karaosmanoğlu'nun himayesine girmeyi memnuniyetle kabul etti ve kendilerini bu ataerkil düzene soktular. Kolonileşme hızla arttı, toprak artık sürülüydü, ticaret gelişti. Tüm ülke kalabalıklaştı ve zenginleşti. Kendine bağlı bir bölgedeki bu zenginlik, kendi ylkıntısı gibi görünen, yönetiminin tek tebaası emri altındakilerin sefaleti olan bir yönetimle bağdaşmamaktadır. Anadolu'nun, Karaosmanoğlu'nun yönettiği bu kesiminin bol mahsullü durumu kıskanç korkuları üzerine çekti ve Sultan Mahmud'un gururunu zedeledi. Kötü kaderli yönetiminin ilk impolitik darbesi büyük kalttsal reislerin kaldırılmasıydı: bunun başarılmasının doğal sonuçları da gelmeye başladı. Karaosmanoğlu ailesi yönetimi bırakalı ve onun yerini paşa alalı on beş yıl oluyor. Geçen bu sürede gerçek bir ylkım yaşandl; toprak nadasta; ticaret azaldl; nüfus hızla azaldl. Burada eskiden yaşayanların bazıları tamamen ortadan kayboldu. Rumlar evlerine döndü ve o zamana kadar devletin otoritesini kendilerinden uzak tutmayı başaran, silahlı hemşehrilerinin arasına katıldl. Pek çok Türk'ü asi Zeybeklerin arasında görmek mümkündü ve burada kalan az sayıdaki sefil köylü, çocukların babalarının yönetimine istekle tabi olduğu yönetimden kölelerin bir zalimin boyunduruğuna girmeye zorlandikları yönetim şekline dönüşmesinden etkilenmemiş görünmekteydiler” (Keppel, 1831:295 $300)$. 
Arundell ise Karaosmanoğlu ailesinin ne kadar başarılı bir yönetim düzeni kurduğunu dile getirirken, bölgede karşısına çıkan bir adamın sergilediği tuhaf davranışlar karşısında, bu adamın aile için çalışan bir muhbir veya Karaosmanoğlu'nun ta kendisi olma ihtimalini düşündürdüğünden bahseder: " $B u$ dakikada oldukça sarhoş görünen bir Derviş fazlaca gürültü yaparak arsızca para istemeye başladl. Yükümüz Ă̆rı Dă̆ı'ndaki gemi kadar sıkı bağlanmıs olduğundan, bunu yapması gereksizdi. Fakat adam fazlasıyla rahatsız ediciydi ve onu uzaklaştırmak için Türkçe'min el verdiği ölçüde azarladım ve sonunda ondan kurtulmay başardım. Han hala oldukça uzaktaydı ve çıkılacak pek çok dik basamak bulunmaktaydl; fakat yolun alternatifi bulunmadı̆̆ından, arabacıya ve slğırlara iyi geceler dileyerek hana doğru zorlukla yürümeye başladım. Kapıya çok yaklaşmıştım ki, arkadaşım Derviş’i tekrar yanımda görünce şaşırmadan edemedim; çok aylk olmayan bir ses tonuyla, fakat medeni ve saygll bir tavırla kulă̆ıma "Hoş geldin” diye fisıldadl. Muhtemelen Sultan veya Karaosmanoğlu için çalışan, kılık değiştirmiş bir casustu; hatta belki de Karaosmanoğlu'nun ta kendisiydi. İbrahim Paşa'nın Güzelhisar'daki başarı ve gelişmesinden, alışılmadık şekilde kapılar kapandıktan sonra gelen ve kapıların tekrar açılmasını isteyen yolcuların iyi bir yöneticinin şüphesini ve soruşturma ihtiyacını uyandırabileceğinden ötürü, bu kişinin bizzat Karaosmanoğlu olması daha muhtemeldi. Sultanın otoritesinin Güzelhisar'da kaybolmasından klsa süre sonrastydı. Valinin yerine İbrahim Paşa ve onun, nüfuzlu bir Misırlı tarafindan desteklenen bir taraftarı gelmişti” (Arundell, 1834:219).

\section{SONUÇ}

19. yüzyılda Batı Anadolu'da Türk halkının yanı sıra hayatlarını idame ettirmekte olan başlıca üç millet bulunmaktadır: Rumlar, Ermeniler ve Yahudiler. Seyahatnamelere konu şehirler ve köylere bakıldığında bu dört millet -az sayıdaki istisnai yerleşimler hariç- aynı fiziki yerleşimde yaşamaktadır. Bununla birlikte halklar, genellikle kendi milletlerinin bulunduğu mahallelere bölünmüsstür. Genel olarak çoğu gezginin azınlıklara dair üzerinde durdukları ortak özellik, azınlıkların Batı Anadolu'da mümkün olan en fazla özgürlüğe sahip oldukları ve yaşantılarından memnun oldukları yönündedir. Değinilmesi gereken bir diğer husus ise, azınlıkların pek azının kendi dillerini konuşabildikleri ve kendi aralarındaki iletişimlerini de Türk dilinde sağladıklarıdır. Pek çok seyyah, azınlıklarla iletişim kurabilmek için tercüman ihtiyacını açıkça dile getirmiştir. Türk halkına dair pek çok gezginin birleştiği temel nokta, tarihi eserler ve üzerinde yaşadıkları toprakların tarihi değeri konusundaki bilgisizlik ve ilgisizlikleridir. Seyyahlar antik yerleşim yerlerinden alınmış sütunların Türk halkınca kendi binalarının yapımında kullanılmasından yakınmaktadır. Onlara göre dönem Türk insanı, sadece Müslüman gelenek ve yapılarına değer vermekte ve kendilerine ait olmayan her türlü yap1 ve dahi tarihi eseri alaşağı etmekte hiçbir sakınca görmemektedir. Türk halkının bu dikkat çekici umursamazlığının yanı sıra, gezginlerin pek çoğu Türk insanının misafirperverliğinden, dürüstlüğünden de bahsetmeyi ihmal etmemiştir. Bununla birlikte, paraya olan düşkünlüklerinden ötürü yaptığı her iyilik karşısında maddi kazanç bekleyen Türklerin varlığı da azımsanmayacak niteliktedir. 19. yüzyılda gezginlerin değinmek ihtiyacı hissettikleri bir diğer konu ise Türk şehir ve köyleridir. Şehirleşme kavramının henüz yerleşmediği Türk illerine dair bilgi paylaşan gezginlerin büyük bölümü sokakların darlığından bahsetmektedir. Arabanın giremeyeceği, hatta bir deveyle bir insanın birbirlerine temas etmeden yürüyemeyeceği kadar dar olan sokakların pek çok il ve köyde aynı derecede pis olduğuna önemle değinilmektedir. Evler genellikle çift katlıdır: Alt katlar ahır olarak kullanılmaktayken, insanların yaşam alanının ise bir üst katta olduğundan bahsedilmektedir. Çoğu evin dişarıya bakan penceresi bulunmamakla birlikte, avlusu olan evlerin pencereleri avluya bakmaktadır. Avlusu olmayan evlerde ise tek 1şık kaynağı genellikle sokak kapısıdır. Avrupalı gezginler, Batı Anadolu Osmanlı'sındaki çarşı ve pazarlardan da oldukça etkilenmiş bulunmaktadırlar. Pazarlardaki cümbüş ve şenlik havası, gezginlerin özellikle ilgisini çekmiştir. Çevre köylerden gelen halkın bir arada yarattığı renkli görüntü, gezginler için bahsedilmeye değer niteliktedir. Konaklama 
konusunda pek çok gezginin birleştiği temel nokta, kalınan hanlardaki elverişsiz koşullardır. Hanlar tek konaklama seçeneği değildir elbette. Bazı illerin paşaları veya valileri gelen gezginleri özel olarak görmek isterler ve bu kişiler, gezginlerin mümkün olduğunca rahat etmelerini sağlamak amaciyla genellikle bölgedeki reayadan varlıklı bir tanesinin evinde konaklama temin edilir. Giyim konusuna gelindiğinde ise, bu konudaki çeşitliliğin ayrıca dikkat çekici olduğu görülmektedir. Her ırk ve meslek mensubunun kendine has giyim tarzı, şehirlerde ve özellikle çarşı ve pazarlarda yarattığı çeşitlilik çoğu zaman baş döndürücü ve göz alıcıdır. Bununla birlikte, beyaz çarşaf içinde ve yüzleri bile tülbentle örtülü kadınlar da Avrupalı gezginler için dikkat çekici bir detaydır. Pek çok gezgin kılık kıyafetteki Avrupalılaşma çabasına değinmiş bulunmaktadır. Fakat bu çabaya gülünç ve eğreti olarak yorum getiren gezginler, köylülerin giydiği renkli basmaların aslında bu kültüre has ve asıl yakışan giyim tarzı olduğundan bahsetmiştir. Batı Anadolu Osmanlısı'nda kadın konusu ise, bahse konu dönemde kadınların hayatlarını dinin emrettiğinin dikta edildiği şekilde kısıtladıkları yönündedir. Sokakta bir erkek gören kadın telaşa kapılarak kaçar veya erkek gözden kaybolana dek sırtını döner ve zaten peçeyle kapalı yüzünü göstermekten kesinlikle kaçınır.

Sonuç olarak, seyahatnamelerine yer verilen Avrupalı on dört gezginin 19. yüzyıl Aydın ili, halkı ve yaşantısı hakkında benimsediği ortak bir görüş veya izlenimden bahsetmek mümkün olmamakla birlikte; birinci el kaynaklar olan bu yazıların dönem Aydın'1 hakkında önemli bilgilerin yanı sıra, başka kaynaklardan edinilmesi mümkün olmayan detaylar sunduğu da görülmektedir.

\section{KAYNAKÇA}

ARUNDELL, Francis Vyvyan Jago Arundell (1834), Discoveries in Asia Minor, Vol: 2, Richard Bentley, London.

CHANDLER, Richard (1817), Travels Asia Minor In Greece Or An Account Of A Tour In Two Volumes - Volume: 1, Printed For Joseph Booker, New Bond Street And Priestley, High Holborn: London.

FELLOWS, Chandler (1852), Travels And Researches In Asia Minor, The Provience Of Lycia, John Murray, Albamarle Street, J.Edward Taylor Little Quenn Street Lincoln's İnn Fields: London.

HAMILTON, William John (1842), Researches In Asia Minor, Pontus And Armenia, Some Account Of Their Antiquites And Geology, Secretary To The Geological Society, Volume: 2, John Murray Albemarle Sreet: London.

HAYKIRAN, Aysun Sarıbey, XIX. Yüzyll Aydın Kent Tarihi Bibliyografyası, Türkiye Cumhuriyeti'nin 90. Yılına Armă̆an, Basılmamış Kitap Bölümü

JARDINE, William (1858), Memoirs of Hugh Edwin Strickland, John Van Voorst \& Paternoster Row: London.

KEPPEL, George Thomas (1831), Narrative of Journey Across The Balcan, By The Selimo And Paravadi Also Of A Visit To Azani And Other Newly Discovered Ruins in Asia Minor, in the Years 1829-30, In Two Volumes, Volume: 2, Henry Colburn and Richard Bentley: London.

KNIGHT, William (1839), Oriental Outlines or a Rambler's Recollections of a Tour in Turkey, Greece, Sampson Low: London. 
LEAKE, William Martin (1824), Journal of a Tour in Asia Minor: with Comparative Remarks on the Ancient and Modern Geography of that Country, John Murray - Albemarle Street: London.

NEWTON, Charles Thomas (1865), Travels and Discoveries in the Levant, Day \& Son: London.

PINAR, İlhan (2001), Hacılar, Seyyahlar, Misyonerler ve İzmir Yabancıların Gözüyle Osmanl Döneminde İzmir 1608- 1918, İzmir Büyükşehir Belediyesi Kültür Yayını: İzmir.

PINAR, İlhan (1996), Gezginlerin Gözüyle İzmir 19. yüzyll II, Akademi Kitabevi: İzmir.

SCHERZER, Karl Von (2001), İzmir 1873, (Çev: İlhan Pınar), İzmir Büyükşehir Belediyesi Kültür Yayını: İzmir.

T.D.K. (1988) Türkçe Sözlük, Türk Tarih Kurumu Basımevi: Ankara.

TEXIER, Charles (2002) Küçük Asya, Coğrafyast, Tarihi ve Arkeolojisi, (Çev: Ali Suad), Enformasyon ve Dokümantasyon Hizmetleri Vakfi Yayınları: Ankara.

TURNER, William (1820), Journal of a Tour in the Levant, Volume: 3, John Murray - Albemarle Street: London.

WILSON, Mark (2006), Thomas Allom's Constantinople and the Scenery of the Seven Churches of Asia Minor, Gorgias Press: the USA.

http://www.amphilsoc.org/ (Er. Tar.: 18/04/2014)

http://www.britannica.com/ (Er. Tar.: 18/04/2014)

http://www.doguedebiyati.com/ (Er. Tar.: 18/04/2014)

http://www.filozof.net/ (Er. Tar.: 18/04/2014)

http://www.forumancientcoins.com/ (Er. Tar.: 18/04/2014)

http://www.historyhome.co.uk/ (Er. Tar: 18/04/2014)

http://www.oac.cdlib.org/ (Er. Tar.: 18/04/2014)

http://www.oxforddnb.com/ (Er. Tar.: 18/04/2014)

http://www.rhinoresourcecenter.com/ (Er. Tar.: 18/04/2014)

http://en.wikipedia.org/ (Er. Tar.: 18/04/2014) 